\title{
Phocid seals, seal lice and heartworms: a terrestrial host-parasite system conveyed to the marine environment
}

\author{
Sonja Leidenberger ${ }^{1, *}$, Karin Harding ${ }^{2}$, Tero Härkönen ${ }^{1}$ \\ ${ }^{1}$ Swedish Museum of Natural History, Box 50007, 10405 Stockholm, Sweden \\ ${ }^{2}$ Department of Marine Ecology, Göteborg University, Box 461, 40530 Göteborg, Sweden
}

\begin{abstract}
Adaptation of pinnipeds to the marine habitat imposed parallel evolutions in their parasites. Ancestral pinnipeds must have harboured sucking lice, which were ancestors of the seal louse Echinophthirius horridus. The seal louse is one of the few insects that successfully adjusted to the marine environment. Adaptations such as keeping an air reservoir and the ability to hold on to and move on the host were necessary, as well as an adjustment of their life cycle to fit the diving habits of their host. E. horridus are confined to the Northern Hemisphere and have been reported from 9 species of northern phocids belonging to 4 genera, including land-locked seal species. The transmission from seal to seal is only possible when animals are hauled-out on land or ice. Lice are rarely found on healthy adult seals, but frequently on weak and young animals. The seal louse is suggested to play an important role as an intermediate host transmitting the heartworm Acanthocheilonema spirocauda among seals. However, the evidence is restricted to a single study where the first 3 larval stages of the heartworm were shown to develop in the louse. The fourth-stage larvae develop in the blood system of seals and eventually transform into the adult stage that matures in the heart. Since all other studies failed to confirm the presence of heartworm larvae in seal lice, other unknown intermediate hosts could be involved in the transmission of the heartworm. Transplacental transmission of microfilariae in seals has been suggested as an additional possibility, but is not likely to be important since the occurrence of heartworms in adult seals is very rare compared with juveniles. Furthermore, there are no findings of the first 3 larval stages in seals. This review shows that the heartworm infects nearly the same species of seals as the seal louse, except for the grey seal Halichoerus grypus, where the heartworm is absent. Prevalence and intensity of infection differ among regions in the Northern Hemisphere. As for seal lice, heartworms mainly infect immature seals, and after infection the prevalence seems to decrease with increasing age of the host.
\end{abstract}

KEY WORDS: Acanthocheilonema spirocauda · Heartworm - Echinophthirius horridus · Seal louse · Intermediate host $\cdot$ Life cycle $\cdot$ Adaptation

\section{INTRODUCTION}

The pinnipeds derived from carnivore ancestors after the separation of Feliformia and Caniformia about 45 million years ago (MYA) (Kulu 1972). Seals gradually adapted to the marine environment before they split between Phocidae and Otarioidea in the
Oligocene ( 33 MYA) (Arnason et al. 2006). The oldest phocid fossil, called the 'Oligocene seal' (28 MYA), was likely accompanied by parasite systems with terrestrial origins (von Sprehn 1966). Some of these parasite systems were probably lost, while others developed together with the seals through evolution. Adaptation of pinnipeds to the marine habitat imposed adaptive 
pressures on their parasites (Tijskens 1969). Pinnipeds are the only marine mammals which have stayed in contact with the terrestrial as well as the marine environment (Ménier 2000). Their parasite fauna is very diverse and includes endo- and ectoparasites. The most common parasites in seals belong to the phyla Nematoda (roundworms), Acanthocephala (spiny-headed worms), and Platyhelminthes (flatworms), with the classes Trematoda (flukes) and Cestoda (tapeworms). Common parasitic arthropods are mites (subclass Acarina) and lice (suborder Anoplura) (Dierauf 2000).

The most frequently reported parasite species in Atlantic harbour seals Phoca vitulina vitulina/concolor are summarised in Table 1. Most of the mentioned endoparasites utilise a number of intermediate hosts. Whereas general biology and intermediate hosts are well known for many of the approximately 25000 trematode species (Sukhdeo \& Sukhdeo 2004), details about the life cycles of parasitic nematodes infecting marine mammals are still scarce. Most investigations are confined to anisakid nematodes and their impact on the fishing industry and on human health. The life cycle of the seal worm/cod worm Pseudoterranova decipiens has been described in several experimental studies (e.g. McCelland 1980a,b, 1982). Eggs are shed with the faeces of the final host (seals), after which eggs hatch to free-living ensheathed larvae (McCelland 2002). First intermediate hosts are meiofaunal copepods, gammarids and amphipods, but also macroinvertebrates such as polychaetes, nudibranchs, mysids, isopods, cumaceans and decapods. Later larval stages infect the flesh of numerous marine and euryhaline fish species (>75 species) that mostly act as second intermediate hosts. The life cycle of the seal worm is completed when the second intermediate host is ingested by a grey seal Halichoerus grypus, although the cod worm is common also in harbour seals Phoca vitulina (McCelland 2002). The cod worm may exemplify a strategy whereby the parasite can have several alternative final hosts.

Klimpel et al. (2004) gave a modified and detailed life cycle for Anisakis simplex, in which copepods, euphausiids and cephalopods, as well as planktivorous and piscivorous fishes, acted as intermediate hosts. Toothed whales, such as porpoises and dolphins, constitute primary final hosts, whereas pinnipeds are assumed to provide suboptimal environments, since the prevalence is lower than in odontocetes and the adult size of $A$. simplex is considerably smaller in pinnipeds (B. Berland pers. comm.). Consequently, A. simplex is assumed to have coevolved with small odontocetes, whereas the parasite is less adapted to completion of its life cycle in pinnipeds. Similar parallel evolutions are seen in canoid carnivores and heartworm species, e.g. in Dirofilariasis immitis that infect terrestrial Canidae (dogs, wolves, foxes, coyotes, dingoes and jackals, etc.) (Lai et al. 2000, Sacks et al. 2002) and in the related heartworm species Acanthocheilonema spirocauda, which infects phocid seals in the Northern Hemisphere.

This review is focussed on the taxonomy and morphology, as well as the distribution and host range, of the heartworm Acanthocheilonema spirocauda and the seal louse Echinophthirius horridus, which is suggested to act as an intermediate host. We further illustrate the adaptation of the seal louse to the marine environment, pathological findings associated with A. spirocauda infectation and the possible life cycle of A. spirocauda based on available information. A comparison with a terrestrial parasite-host system in dogs will also be discussed.

Table 1. Most frequently identified parasite species (larvae, immature or mature form) in Atlantic harbour seals. N: Nematode; C: Cestode; A: Acanthocephala; T: Trematoda

Parasite species

Cryptocotyle lingua Creplin, 1825 (T)

Phagicola septentrionalis van de Broek, 1967 (T)

Diphyllobothrium elegans Krabbe, 1865 (C)

Diphyllobothrium cordatum Leukart, 1863 (C)

Acanthocheilonema spirocauda Leidy, 1858 (N)

Anisakis simplex (Rudolphi, 1809) (N)

Phocascaris cystophorae/spp. Bergland, 1963 (N)

Contracaecum osculatum (Rudolphi, 1802) (N)

(Pseudo-) Terranova decipiens (Krabbe, 1878) (N)

Otostrongylus circumlitus (Raillet, 1899) (N)

Parafilaroides gymnurus Raillet, 1899 (N)

Corynosoma strumosum Rudolphi, 1802 (A)

Echinophthirius horridus von Olfers, 1816 (Anoplura)

\section{West Atlantic}

\section{$-$}

$-$

$-$

Measures et al. (1997)

Stobo et al. (2002)

Brattey \& Stenson (1993)

Stobo et al. (2002)

Stobo et al. (2002)

Gosselin et al. (1998)

Gosselin et al. (1998)

Hoffmann et al. (2004)
Source

East Atlantic

Strauss et al. (1991)

Strauss et al. (1991)

Strauss et al. (1991)

Strauss et al. (1991)

Claussen et al. (1991)

Ólafsdóttir \& Hauksson (1998)

Ólafsdóttir \& Hauksson (1998)

Claussen et al. (1991)

Claussen et al. (1991)

Claussen et al. (1991)

Claussen et al. (1991)

Strauss et al. (1991)

Thompson et al. (1998) 
Table 2. Acanthocheilonema spirocauda (Leidy, 1858) Anderson, 1992. Taxonomic hierarchy and synonyms of the heartworm

\begin{tabular}{|ll|}
\hline Taxonomic hierarchy (Anderson 2000) & Synonyms \\
\hline Phylum: Nematoda & $=$ Filaria spirocauda Leidy, 1858 \\
Class: Secernentea & $=$ Filaria cordis phocae Joly, 1858 \\
Order: Spirurida & $=$ Skrjabinaria spirocauda (Leidy) Lubimov, 1927 \\
Suborder: Spirurina & $=$ Skrjabinaria heteromorpha Kreis, 1953 \\
Superfamily: Filarioidea & $=$ Dipetalonema spirocauda Anderson, 1959 \\
Family: Onchocercidae & $=$ Dipetalonema (Acanthocheilonema) spirocauda \\
$\quad$ Subfamily: Onchocercinae & Anderson and Bain, 1976 \\
Genus: Acanthocheilonema Cobbold, 1870 & \\
Species: spirocauda Anderson, 1992 & \\
\hline
\end{tabular}

\section{THE HEARTWORM ACANTHOCHEILONEMA SPIROCAUDA (LEIDY, 1858) ANDERSON, 1992}

\section{Taxonomy and morphology}

The heartworm of harbour seals Phoca vitulina vitulina was first described by Leidy (1858) as Filaria spirocauda, and somewhat later by Joly (1858) as F. cordis phocae. The taxonomy has been revised several times, resulting in name changes (Table 2). Railliet \& Henry (1910) transferred the heartworm, together with other filarioids, to the new genus Dipetalonema. Later, Lubimov (1927) published a similar description in which the worm was named Skrjabinaria spirocauda. Chabaud (1952) used the genus name Dipetalonema in his taxonomical description, whereas Kreis (1953) described heartworms found in captive harbour seals as $S$. heteromorpha. Using specimens from earlier descriptions as well as new material, Anderson (1959) reviewed the taxonomy of the heartworm and gave a full re-description of $D$. spirocauda. In this process it was noticed that the descriptions of Leidy (1858) and Joly (1858) were so general that the worms could belong either to Dipetalonema spirocauda or Dirofilaria immitis and that the female worm described by Lubimov (1927) did not belong to the filarioids, but seemed to be a metastrongyle. The descriptions of the male worm of Lubimov (1927) and the worm of Kreis (1953) were identical with those of D. spirocauda, and, therefore, $S$. spirocauda/heteromorpha are regarded as synonyms (Anderson 1959). Anderson \& Bain (1976) mentioned the heartworm in their keys to the genera of the order Spirurida as Dipetalonema (Acanthocheilonema) spirocauda. Later Bain et al. (1982) raised the subgeneric Acanthocheilonema to generic status, and 10 yr later Anderson (1959, 1992) presented the recent name $A$. spirocauda for the heartworm nematode for the first time.

The genus Acanthocheilonema belongs to the subfamily Onchocercinae (Table 2). A typical characteristic of this genus is the lamina of the right spicule, which is simple and spoon-shaped, and the lamina of the left spicule that is generally longer than the shaft in contrast to other genera (Anderson \& Bain 1976). The glandular oesophagus is much broader than the muscular one. The cephalic extremity is flat or convex in a lateral view. The A. spirocauda is a long, slender nematode with a tapering extremity. Anderson (1959) described the anterior end as round, without cuticular structures, but with 4 pairs of submedian papillae and lateral amphids, whereas the oral opening is surrounded by a cuticular ring leading into a cavity with a thick, curved refractory wall (Fig. 1D). The wall and oesophagus are separated by a big cuticular ring. The oesophagus is rather short and is divided into a short anterior muscular part and a broader posterior glandular part (Anderson 1959) (Fig. 1E). The cuticula is thin, often with regular transverse striations. Males and females differ in some specific morphological charac-

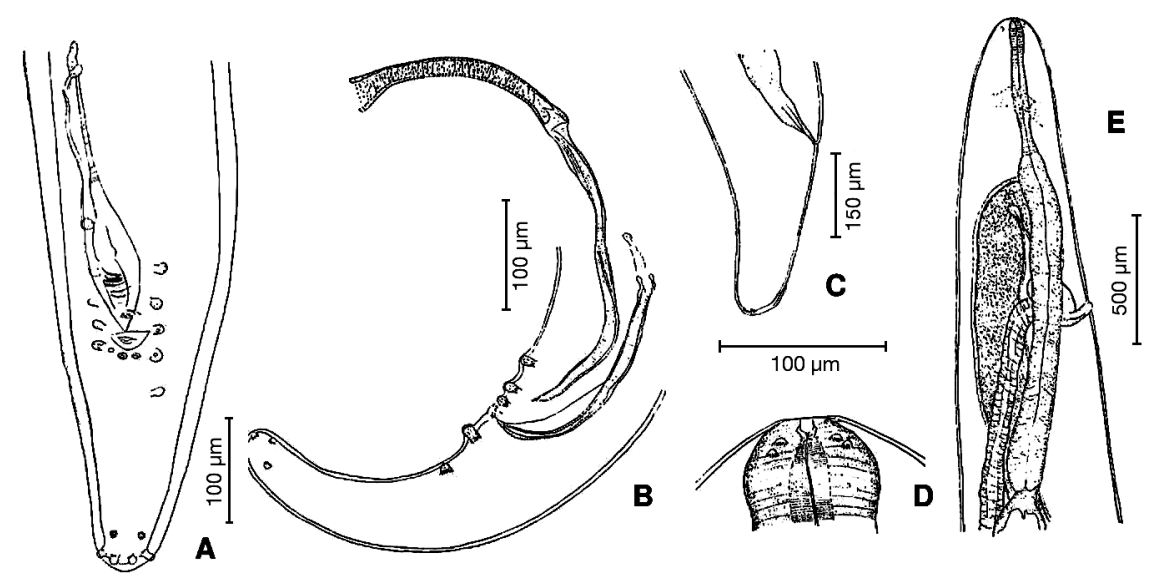

Fig. 1. Acanthocheilonema spirocauda. Male caudal end (A) lateral view and (B) ventral view and female (C) caudal end, lateral view, (D) lateral view, anterior end and (E) anterior end, lateral view 
teristics. Whereas the female has a single terminal papilla, the male has well-defined and arranged numbers of caudal papillae (Fig. 1A,B): 3 pairs of preanal papillae, 5 smaller papillae in a row behind the anus, a single broad median papilla before the anus, an unpaired papilla on the left side of the ventral surface behind the anus (Fig. 1B), a pair of papillae on the ventrolateral surface of the caudal extremity and 2 pairs of terminal papillae (Fig. 1A) (Anderson 1959). Male spicules differ in size (Wülker 1930). The left spicule, consisting of tubular calornus and membranous lamina, is $0.47 \mathrm{~mm}$ in length, whereas the right one is 0.21 to $0.27 \mathrm{~mm}$ in length (Anderson 1959). The capitula of the spicules is weakly developed, and a gubernaculum is absent. An excretory pore is distinct in females, but not present in males (Anderson 1959). The female vulva is 1.2 to $1.3 \mathrm{~mm}$ from the anterior extremity and has 2 lateral rounded flaps. The anterior of the vagina is sharply bent and bound with ligament, which is typical of the genus Acanthocheilonema.

Borgesteede et al. (1991) mentioned entangled worms that were difficult to separate. This is probably the reason why only a few published measurements of the size of adult Acanthocheilonema spirocauda are available (Table 3). However, the average length of males is about $9.0 \mathrm{~cm}$ and the width $0.37 \mathrm{~mm}$, whereas female worms are larger, with mean lengths and widths at 14.9 $\mathrm{cm}$ and $0.66 \mathrm{~mm}$ (Anderson 1959).

Female worms shed microfilariae (mf) in the blood of their host (Dailey 1978). Circulating in the blood of seals, $\mathrm{mf}$ are unsheathed and have attenuated, pointed tails (Anderson \& Bain 1976, Anderson 2000). The life cycle of Acanthocheilonema spirocauda is not fully understood, but filarioid $\mathrm{mf}$ are known to transform into 4 different larval stages.

Taylor et al. (1961) described the mf of Acanthocheilonema spirocauda found in blood smears as unsheathed and exceedingly slender, with greatly extenuated caudal extremities, $235 \pm 10 \mu \mathrm{m}$ in length and $5.4 \mu \mathrm{m}$ in width. The measurements of Geraci et al. (1981) are significantly greater than those of Taylor: $286 \pm 10 \mu \mathrm{m}$ in length and $5.3 \pm 0.5 \mu \mathrm{m}$ in width $(\mathrm{N}=40)$. The authors suggested that the differences might be explained by differences in used fixation techniques. Whereas Geraci et al. (1981) centrifuged $1 \mathrm{ml}$ of blood with $10 \mathrm{ml}$ of $2 \%$ formalin and placed an aliquot of the pellet on a glass slide, Taylor et al. (1961) used the thick blood smear (TBS) technique and stained with Giemsa's stain.

The $\mathrm{mf}$ transform into first-stage larvae (Fig. 2A), which Geraci et al. (1981) described as a short, thick 'sausage' stage, which becomes longer, develops a tail and a protruding cephalic knob $(280 \pm 60 \mu \mathrm{m}$ in length; $-8.4 \pm 5.7 \mu \mathrm{m}$ in width; $\mathrm{N}=66$ ). After moulting into the

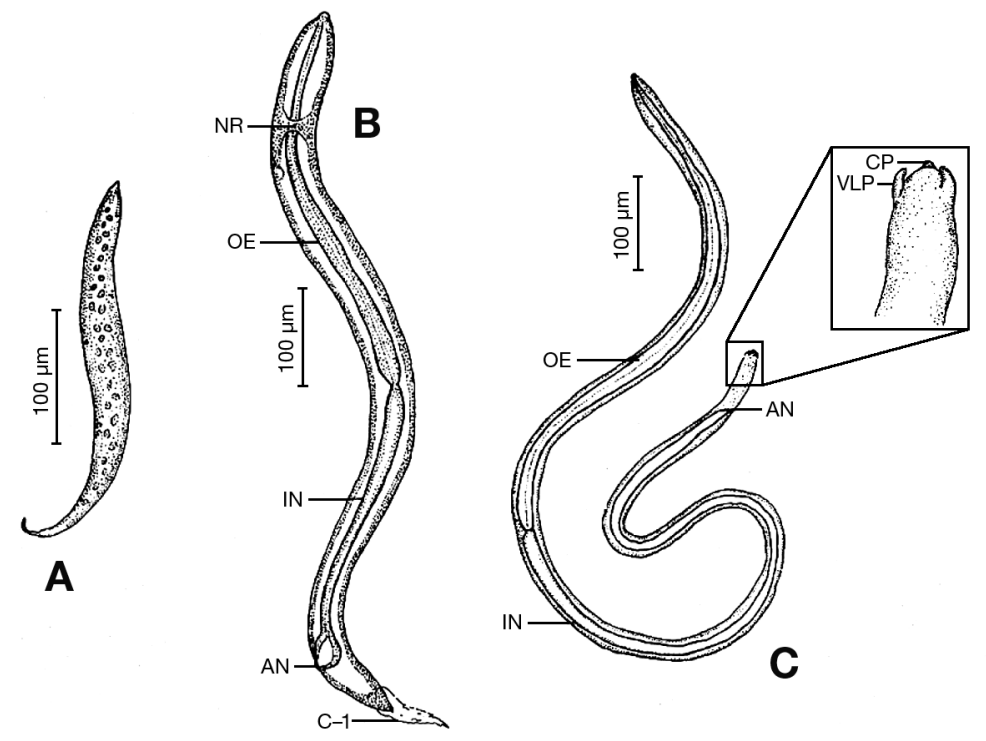

Fig. 2. Acanthocheilonema spirocauda. Laval stages of heartworms (lateral view): (A) first-stage, (B) second-stage (AN: anus; C-1: remnant of first-stage cuticule; IN: intestine; NR: nerve ring; OE: oesophagus), (C) third-stage (AN: anus; CP: caudal papilla; IN: intestine; OE: oesophagus; VLP: ventrolateral papilla) (Geraci et al. 1981)

Table 3. Acanthocheilonema spirocauda. Number (N) and measurements of adult male and female heartworms found in Phoca vitulina. -: no data

\begin{tabular}{|c|c|c|c|c|c|c|c|c|}
\hline \multirow{3}{*}{$\mathrm{N}$} & \multirow{3}{*}{$\begin{array}{l}\text { Width } \\
(\mathrm{mm})\end{array}$} & \multirow{2}{*}{\multicolumn{2}{|c|}{$\begin{array}{l}\text { Iale worm } \\
\qquad- \text { Length }\end{array}$}} & \multirow{3}{*}{$\mathrm{N}$} & \multirow{3}{*}{$\begin{array}{l}\text { Width } \\
\text { (mm) }\end{array}$} & \multicolumn{2}{|c|}{ Female worm } & \multirow[t]{3}{*}{ Source } \\
\hline & & & & & & — Len & 1 & \\
\hline & & $\begin{array}{l}\text { Range } \\
(\mathrm{cm})\end{array}$ & $\begin{array}{c}\text { Mean } \\
(\mathrm{cm})\end{array}$ & & & $\begin{array}{l}\text { Range } \\
\text { (cm) }\end{array}$ & $\begin{array}{c}\text { Mean } \\
(\mathrm{cm})\end{array}$ & \\
\hline 4 & _- & $10.4-11.4$ & 10.8 & - & _- & _- & - & Measures et al. (1997) \\
\hline- & 0.50 & - & 9.0 & - & 0.50 & - & 15.0 & Borgesteede et al. (1991) \\
\hline - & 0.50 & $9.0-15.0$ & - & - & 0.50 & $9.0-15.0$ & - & van der Kamp (1987) \\
\hline- & - & $11.0-(18.0)$ & - & - & - & $11.0-18.0$ & - & Wipper (1974) \\
\hline- & - & - & - & - & 0.30 & - & 15.0 & van den Broek \& Wensvoort (1959) \\
\hline 2 & $0.33-0.40$ & $8.7-9.3$ & 9.0 & 2 & 0.66 & $14.3-15.5$ & 14.9 & Anderson (1959) \\
\hline 4 & - & $11.0-12.0$ & - & 7 & 0.70 & $15.0-17.0$ & - & Leidy (1858) \\
\hline
\end{tabular}




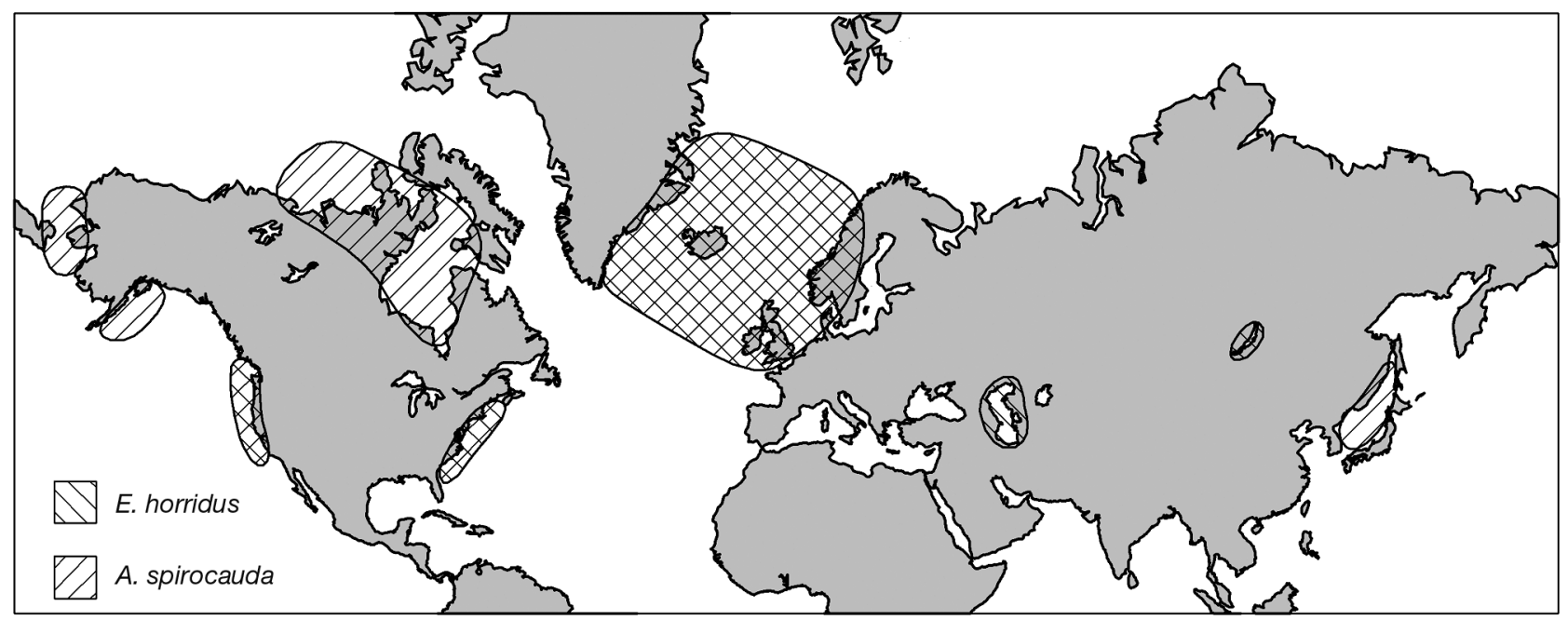

Fig. 3. Map of distribution of Acanthocheilonema spirocauda and Echinophthirius horridus in the Northern Hemisphere

second larval stage, these structures are lost and the second-stage larva is longer and thicker than the first stage $(923 \pm 202 \mu \mathrm{m}$ in length; $29.7 \pm 3.2 \mu \mathrm{m}$ in width; $\mathrm{N}=7$ ) (Fig. 2B). The third larval stage is likewise longer, but thinner $(1470 \pm 497 \mu \mathrm{m}$ in length; $23.8 \pm 3.2 \mu \mathrm{m}$ in width; $N=31$ ). Larvae in this stage have 1 caudal papilla and 2 ventrolateral 'ears' at the posterior end (Geraci et al. 1981) (Fig. 2C).

No additional larval stages have been described for Acanthocheilonema spirocauda, except by Raga (1992), who mentioned a fourth larval stage without giving detailed descriptions.

\section{Epizootiology}

Distribution and host range

Most investigations on Acanthocheilonema spirocauda have been carried out in the Northern Hemisphere, and only limited information is available for southern pinnipeds. However, since no finds of the heartworm have been reported from the Southern Hemisphere (Lauckner 1985), the spatial distribution of $A$. spirocauda seems to be limited to the Northern Hemisphere, where it has a holarctic distribution (Fig. 3). Although A. spirocauda seems to be an ancient species, originating from the parasitic nematodes infecting terrestrial ancestors of seals (von Sprehn 1966, Anderson 1984, Ménier 2000), the heartworm is confined to phocid seals and has not been reported to occur in Otariinae or Monachinae (Dailey 1975).

The filarioid heartworm infects a variety of phocid seals, encompassing 3 genera and 7 species or subspecies. The heartworm does not seem to have any preferred host species within this group of seals, since adult worms from different phocid species are all of similar size (Measures et al. 1997).

Acanthocheilonema spirocauda is commonly reported in harbour seals Phoca vitulina (subspecies $P$. v. vitulina, P. v. concolor and P. v. richardii). It has also been reported in P. V. stejnegeri (Nagasawa 1999) (Table 4, Fig. 3). In addition, the heartworm occurs in hooded seals Cystophora cristata (Delamure \& Treshchev 1966, Helle \& Blix 1973, Pouvreau et al. 1980, Measures et al. 1997), bearded seals Erignathus barbatus (Popov 1975a, Eley 1981), ribbon seals P. fasciata (Popov 1975b, Eley 1981, Shults \& Frost 1988), harp seals $P$. groenlandica (Measures et al. 1997), ringed seals $P$. hispida (King 1964, Delamure \& Popov 1974, Dailey 1975, Popov 1975a, Treshchev \& Yurakhno 1975, Eley 1981, Measures \& Gosselin 1994, Measures et al. 1997) and spotted seals P. largha (Popov 1975a, Delamure et al. 1976, Goltsev et al. 1978, Eley 1981, Shults 1982).

Perry (1967) described a related species to Acanthocheilonema (Dipetalonema) infecting California sea lions Zalophus californianus named Dipetalonema odendhali. This species differs from A. spirocauda in being of a smaller size (male: 4.6 to $6.4 \mathrm{~cm}$ length, mean $5.4 \mathrm{~cm}$; female: 10.0 to $15.0 \mathrm{~cm}$ length, mean $11.8 \mathrm{~cm}$ ), having a proportionally longer oesophagus and longer tail in both sexes. A further difference between the species is the location where worms are found. According to Perry's description, D. odendhali occurred in subcutaneous and intermuscular sites of Z. californianus, and not in the heart. A high infection rate of California sea lions was also noted by Dailey (1975). Lauckner (1985) mentioned that D. odendhali does not have as high a zoonotic potential as A. spirocauda.

Anderson (1959) mentioned the occurrence of Acanthocheilonema spirocauda in northern fur seals Callo- 
Table 4. Acanthocheilonema spirocauda. Records of heartworms found in harbour seals Phoca vitulina. P: prevalence; D: cause of seal death; C: captive, H: hunting, N: netting, S: stranded, PDV: phocine distemper virus; -: no data

\begin{tabular}{|c|c|c|c|c|c|}
\hline $\begin{array}{l}\text { Subspecies } \\
\text { of } P \text {. } \\
\text { vitulina }\end{array}$ & Location & $\begin{array}{l}\text { Examined/ } \\
\text { infected } \\
\text { seals }\end{array}$ & $\mathrm{P}(\%)$ & $\mathrm{D}$ & Source \\
\hline \multirow{16}{*}{ vitulina } & \multicolumn{5}{|l|}{ Europe } \\
\hline & Denmark/North Sea-Limfjord-Kattegat & it $65 / 16$ & 24.6 & $\mathrm{H} / \mathrm{N} / \mathrm{S} / \mathrm{C}$ & Clausen (1978) \\
\hline & Germany/North Sea & $18 / 2$ & 11.1 & - & Menschel et al. (1966) \\
\hline & Germany/Sylt & $25 / 2$ & 8.0 & PDV & Breuer et al. (1988) \\
\hline & Germany/Wadden Sea & $115 / 37$ & 32.2 & PDV & Claussen et al. (1991) \\
\hline & Germany/Wadden Sea & $93 / 36$ & 38.7 & $\mathrm{H} / \mathrm{S}$ & Wipper (1974) \\
\hline & Ireland/Irish Sea & $76 / 12$ & 15.8 & PDV & Kennedy et al. (1989) \\
\hline & Iceland/entire coast & $15 / 3$ & 20.0 & $\mathrm{H}$ & Skirnisson \& Ólafsson (1990) \\
\hline & Netherlands/Texel & $24 / 12$ & 50.0 & $\mathrm{~S}$ & Van den Broek \& Wensvoort (1959) \\
\hline & Netherlands/Terschelling & $48 / 21$ & 43.8 & $\mathrm{~S}$ & van den Broek (1963) \\
\hline & Netherlands/Wadden Sea & $54 / 4$ & 7.4 & $\mathrm{H} / \mathrm{S}$ & van der Kamp (1982) \\
\hline & Netherlands/Wadden Sea & $363 / 44$ & 9.5 & $\mathrm{H} / \mathrm{S}$ & van Haaften (1982) \\
\hline & Netherlands/Wadden Sea & $12 / 8$ & 66.7 & - & 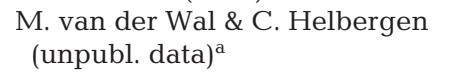 \\
\hline & Netherlands/Wadden Sea & $34 / 1$ & 2.9 & $\mathrm{C}$ & van der Kamp (1987) \\
\hline & Netherlands/Wadden Sea & $94 / 23$ & 24.5 & PDV & Borgsteede et al. (1991) \\
\hline & Sweden/Kattegat-Skaggerak-Baltic & $158 / 18$ & 11.4 & PDV & Lunneryd (1992) \\
\hline \multirow[t]{6}{*}{ concolor } & \multicolumn{5}{|l|}{ USA east/Canada } \\
\hline & Canadian Arctic & $18 / 2$ & 11.1 & $\mathrm{H} / \mathrm{N}$ & Measures et al. (1997) \\
\hline & Nova Scotia/Sable Island & $15 / 2$ & 13.3 & $\mathrm{C}$ & McCelland (1980c) \\
\hline & Nova Scotia/Sable Island & $5 / 4$ & 80.0 & $\mathrm{C}$ & Dunn \& Spotte (1974) \\
\hline & Rhode Island/Connecticut & $5 / 5$ & 100 & $\mathrm{~S} / \mathrm{C}$ & Dunn \& Wolke (1976b) \\
\hline & New England coast & $108 / 41$ & 38.0 & $\mathrm{~S}$ & Geraci (1978) \\
\hline \multirow[t]{8}{*}{ richardii } & \multicolumn{5}{|l|}{ USA west } \\
\hline & California/Los Angeles & $5 / 5$ & 100 & $\mathrm{C}$ & Brown et al. (1960) \\
\hline & Southern California & $5 / 5$ & 100 & $\mathrm{C}$ & Taylor et al. (1961) \\
\hline & Los Angeles Country & $13 / 2$ & 15.4 & $\mathrm{~S}$ & Schroeder et al. (1973) \\
\hline & San Diego/California & $13 / 4$ & 30.8 & - & Sweeney (1973) \\
\hline & Oregon coast & $18 / 2$ & 11.1 & $\mathrm{~S}$ & Stroud \& Dailey (1978) \\
\hline & Grays Harbor/Washington & $77 / 36$ & 47.0 & $\mathrm{C} / \mathrm{S}$ & Dailey \& Fallace (1989) \\
\hline & Alaska & $99 / 17$ & 17.2 & $\mathrm{H}$ & Eley (1981) \\
\hline \multicolumn{6}{|c|}{ stejnegeri Asia } \\
\hline & Japan Sea & - & - & - & Nagasawa (1999) \\
\hline
\end{tabular}

rhinus ursinus, but added that none of the worms were in good enough condition for detailed description. It is therefore likely that the observed nematodes were Dipetalonema odendhali as suggested by Perry (1967), since $A$. spirocauda has not been confirmed by later investigations. Further, Perry \& Forrester (1971) also found $D$. odendhali in the right thoracic area in the fascia between the muscles and the fascia beneath the blubber in some northern fur seals. Machida (1977) reassigned the worms he found in 1969 in the subfascia of the cervical and thoracic region of Japanese C. ursinus from $A$. spirocauda to $D$. odendhali, because of the organs they infected. The $\mathrm{mf}$ of $A$. spirocauda (225 to $296 \mu \mathrm{m}$ in length; 4.8 to $5.8 \mu \mathrm{m}$ in width) and $D$. odendhali ( 225 to $250 \mu \mathrm{m}$ in length, 3.5 to $4.4 \mu \mathrm{m}$ in width) are similar in size, but do not infect the same host species (Howard et al. 1983). D. odendhali are found in the blood of the northern fur seal C. ursinus and the California sea lion Zalophus californianus (Perry 1967, Perry \& Forrester 1971, Forrester et al. 1973), whereas A. spirocauda seems to infect phocid seals only.

Acanthocheilonema spirocauda had not been reported from grey seals Halichoerus grypus. This led Measures et al. (1997) to suggest that a larger sample size of young grey seals from a broad geographic area would be needed to detect heartworm infections in this species. However, no heartworms were found in a sample examined at the Swedish Museum of Natural History (B.-M. Bäcklin pers. comm.), although it encompassed 103 yearlings, 144 aged 1 to $5 \mathrm{yr}$, and 168 older than 5 yr. Consequently, grey seals seem to escape $A$. spirocauda infection.

Since the vulnerability to heartworm infection could vary among species, we have compared the geograph- 
ical patterns in prevalence and intensity of infection of the heartworm in harbour seals, which have a circumpolar distribution, and split the seal species into subspecies. In Europe, the heartworm is found in Phoca vitulina vitulina in the whole Wadden Sea region, as well as in the Irish Sea, on the coast of Iceland, in the Kattegat-Skagerrak and in the Baltic region (Table 4). Most examined seals were hunted or collected during the PDV (phocine distemper virus) epidemic. The prevalence of infections ranged between 8.0 and $32.2 \%$ among seals collected during the PDV epidemic in 1988. High prevalence (43.8 to $50.0 \%$ ) was also noted in seals stranded in the Netherlands during the 1960s. The subspecies $P$. v. concolor and $P$. v. richardii have similar prevalence among hunted, netted, or captive seal samples (11.1 to $47.0 \%$ ). Examined stranded seals of $P . \quad V$. richardii showed prevalence values ranging between 11 and $15.5 \%$. Higher reported prevalence is mostly based on very small sample sizes (Table 4). Since the prevalence and intensity of infection are affected by the general health status of individual seals (Measures et al. 1997), studies of regional differences in the prevalence of heartworms require carefully designed sampling program. Large samples from mass mortality events, by-catches and material from hunted populations are more likely to provide unbiased data, whereas material from captive and stranded animals could be severely biased and not representative of the population.

\section{Microhabitat}

Most heartworms are found in the right ventricle of the heart and in the pulmonary arteries, as described for the first time in a harbour seal (Leidy 1858, Anderson 2000). Acanthocheilonema spirocauda has been located in the heart in most studies (Leidy 1858, Freund 1933, Anderson 1959, van den Broek \& Wensvoort 1959, Menschel et al. 1966, Helle \& Blix 1973, Sweeney 1973, Lauckner 1985, Breuer et al. 1988, Kennedy et al. 1989, Skirnisson \& Olafsson 1990, Claussen et al. 1991, Lunneryd 1992), more specifically in the right ventricle (Anderson 1959, Brown et al. 1960, Delamure \& Treshchev 1966, MacDonald \& Gilchrist 1969, Wipper 1974, Dunn \& Wolke 1976b, Dailey 1978, Geraci 1978, Conlogue et al. 1980, Eley 1981, Reijnders et al. 1981, Shults 1982, van der Kamp 1987, Measures et al. 1997), but it has also been found in the pulmonary artery (Anderson 1959, Delamure \& Treshchev 1966, Menschel et al. 1966, MacDonald \& Gilchrist 1969, Dunn \& Wolke 1976b, Stroud \& Dailey 1978, Conlogue et al. 1980, Eley 1981, Reijnders et al. 1981, van der Kamp 1987, Measures et al. 1997), in the vena cava caudalis (Borgesteede et al. 1991), in the chorda tendineae and truncus pulmonalis (Wipper 1974), the aorta (McCelland 1980c), the lungs (van den Broek \& Wensvoort 1959, Measures et al. 1997), in mesenteries (Dailey 1978) and in testicular sheath (Shults \& Frost 1988).

Another interesting aspect is the age structure of infected seals. Delamure \& Treshechev (1966), as well as Popov (1975b), observed that Acanthocheilonema spirocauda primarily infects pups of the year and immature (1 to $4 \mathrm{yr}$ ) seals. They also suggested that severely infected individuals may not survive heartworm infections. Claussen et al. (1991) and Borgsteede et al. (1991) observed high prevalence in younger seals, and Measures et al. (1997) mentioned that $A$. spirocauda was found in 14 of 19 immature seals. This pattern is repeated in other parts of the distribution area of A. spirocauda (Dailey \& Fallace 1989), and seals younger than 4 yr in the Skagerrak carried $69 \%$ of all heartworms examined by Lunneryd (1992). Consequently, the prevalence of infection decreases with increasing age of the host in most studies, whereas this pattern was not found by Dailey \& Fallace (1989). We suggest that once infected, a seal cannot escape the heartworm, which eventually will have lethal consequences. This would explain the low prevalence of heartworms in older seals.

It has been suggested that females and males become infected to a similar extent, and that the infection has a seasonal component, where highest infection rates of Acanthocheilonema spirocauda occur during the summer, and lowest in the spring (Dailey \& Fallace 1989). Claussen et al. (1991) suggested that higher numbers of heartworms could occur in underfed (blubber thickness $<11 \mathrm{~mm}$ ) and ill-fed (11 to $15 \mathrm{~mm}$ ) seals compared to well-fed (>15 mm) seals, but their results are not clearly presented. Neither Lunneryd (1992) nor Measures et al. (1997) could correlate differences in body conditions with heartworm infection.

\section{Clinical signs and pathology}

Attributing specific clinical signs to Acanthocheilonema spirocauda infection is difficult, since most examined seals have multiple infections, including the lungworms Otostrongylus circumlitus and Parafilaroides spp. (Measures 2001). Various signs, such as fatigue, anorexia, emaciation and dehydration, as well as coughing, nasal discharge, bronchiospasm, dyspnoea and erratic breathing patterns, are typical for heavy filariasis (Brown et al. 1960, Sweeney 1978, Lauckner 1985, Dailey 2001, Measures 2001). In addition to a high respiratory rate after minimal effort, the animals show listlessness (Brown et al. 1960, Wallach 1972).

Microfilariae are observed in the lumen of vessels, the hepatic and spleenic parenchyma, or in acute 
lesions, and in the blood (Dunn \& Wolke 1976a). Acanthocheilonema spirocauda infection in living seals can be confirmed by the presence of $\mathrm{mf}$ in TBS (Taylor et al. 1961, Dunn \& Spotte 1974, Sweeney 1978, Dailey 2001), but this technique can sometimes miss positive cases (Menschel et al. 1966). A new, more sensitive, simpler and less-time-consuming method used for diagnosis of $\mathrm{mf}$ (hematoparasites/filariasis) is the quantitative buffy coat (QBC) technique, e.g. for heartworm infections with Dirofilaria immitis in dogs (Wang 1998) or malaria infections in humans (Estacio et al. 1993). Other methods to detected $\mathrm{mf}$ in dogs $(D$. repens, $D$. immitis, A. reconditum) are Knott's test (Svobodová et al. 2006), a simple molecular method (Casiraghi et al. 2006), the serological (filter) test, and frequently used immunological methods for detecting circulating antibodies or antigens (Sacks et al. 2002). Experience with these modern methods with regard to A. spirocauda are still lacking, and such tests must be validated before using them in wildlife populations.

Pathological changes linked to heartworm infection have been observed in the lungs, heart and liver. Severe infection can be detrimental to the host (Howard et al. 1983, van der Kamp 1987). Pathological processes are mainly initiated by endarteritis of the pulmonary artery and its branches due to chronic, mechanical, or metabolic activity of the worms (Otto \& Jackson 1969, Stroud \& Dailey 1978). The endarteritis progresses into thickening of intima, as a proliferation of the endothelial layer (Dunn \& Wolke 1976b). The reduced elasticity of arteries results in increased pressure in the pulmonary artery, the right side of the heart and the venae cavae. Other common signs are obstructions of the pulmonary arteries, inflammation and thrombosis with subsequent infarct in the parenchyma of the lung (Sweeney 1973, Stroud \& Dailey 1978, van der Kamp 1987, Breuer et al. 1988, Vercruysse et al. 2003). Dead adult worms can also form verminous emboli (Otto \& Jackson 1969, Dunn \& Wolke 1976b). Congestion and oedema in all lobes of the lung have been reported by MacDonald \& Gilchrist (1969). The lungs often show hepatisation and diffuse or granulomatous pneumonia (Brown et al. 1960, Menschel et al. 1966, Dunn \& Wolke 1976b). Geraci \& Aubin (1986) suggested that complications associated with heartworm infection and reduction in lung capacity would reduce the ability to dive and forage.

Cardiac changes are limited to dilatation and hypertrophy of the right chamber of the heart (Taylor et al. 1961, Sweeney 1974, Gulland et al. 2001) as a result of increased pressure caused by partial blockade of the pulmonary artery (Otto \& Jackson 1969). The right atrium and venae cavae are noticeably enlarged, resulting from assemblies of worms obstructing blood flow. However, no significant differences in the weights of hearts of infected seals compared to noninfected animals have been reported (Eley 1981). In addition to macroscopic lesions in the heart and cardiovascular and pulmonary arterial lesions, microscopic lesions in the lungs, liver, spleen and vascular system have been observed (Dunn \& Wolke 1976a). Heartworm-infected seals may also be more susceptible to secondary bacterial infections (McDonald \& Gilchrist 1969, Dunn \& Wolke 1976a,b, Howard et al. 1983, Measures et al. 1997). Hepatic lesions are passive congestion and centrilobular necrosis of the central veins (Otto \& Jackson 1969), or vary from acute eosinophilic necrosis to chronic focal granulomas with foreign body giant cells (Dunn \& Wolke 1976a,b). Some of the pathological changes may be irreversible, especially after long infections.

\section{THE SEAL LOUSE ECHINOPHTHIRIUS HORRIDUS (VON OLFERS, 1816) FAHRENHOLZ, 1919}

Taxonomy and morphology

Sucking lice (Anoplura) are obligate, permanent ectoparasites of pinnipeds, and were mentioned in the scientific literature $200 \mathrm{yr}$ ago (von Olfers 1816). Morphological and biological traits and host specificity of echinophthiriids suggest that the lice must have coevolved with their hosts and been harboured by ancestors to seals before they ventured into the marine environment (Kim 1975, Kim et al. 1975, Ménier 2000). Pinnipeds are infected with a unique group of anoplurid lice, distinct from those found in other carnivores, which has been used as an argument supporting the hypothesis that the pinniped order must have differentiated as a single group from one ancestral canoid carnivore (Hopkins 1949). Later the monophyletic origin of pinnipeds was demonstrated by immunological study (Sarich 1969), as well as a molecular one (Arnason et al. 2006).

The family Echinophthiriidae consists of 5 distinct genera and 12 known species (Durden \& Musser 1994). The most diverse taxon is the genus Antarctophthirus, which includes 6 species and occurs in both hemispheres. The lice infected a wide range of pinniped hosts mainly within the families Otariidae, Odobenidae and Phocidae (Monachinae) (Kim et al. 1975, Durden \& Musser 1994). The genus Echinophthirius is monotypic with the species E. horridus and has a Holarctic distribution in the Northern Hemisphere, where it only infects true seals (Phocidae). The genus Proechinophthirius includes 2 species often found on seals within the Otariinae and Arctocephalinae. The genus Lepidophthirus, encompassing 2 species, infects monk seals Monachus monachus and southern elephant 
Table 5. Echinophthirius horridus (von Olfers, 1816) Fahrenholz, 1919. Taxonomic hierarchy and synonyms of the seal louse

\begin{tabular}{|ll|}
\hline Taxonomic hierarchy & Synonyms \\
\hline Phylum: Arthropoda & $=$ Pediculus horridus von Olfers, 1816 \\
Subphylum: Hexapoda & $=$ Pediculus phocae Lucas, 1834 \\
Class: Insecta & $=$ Pediculus setosus Burmeister, 1838 \\
Order: Phthiratera & $=$ Haematopinus setosus Denny, 1842 \\
Suborder: Anoplura & $=$ Haematopinus annulatus Schilling \& Gurlt, 1857 \\
Superfamily: Echinophthirioidea & $=$ Haematopinus (Echinophthirius) setosus Giebel, 1871 \\
Family: Echinophthiriidae & $=$ Echinophthirius setosus Piaget, 1880 \\
Genus: Echinophthirius Giebel, 1871 & $=$ Echinophthirius groenlandicus Becher, 1886 \\
Species: horridus (von Olfers 1816) Fahrenholz, 1919 & $=$ Echinophthirius sericans Meinert, 1897 \\
& $=$ Echinophthirius phocae Enderlein, 1904 \\
\hline
\end{tabular}

seals Mirounga leonina (Kim et al. 1975, Durden \& Musser 1994). The genus Latagophthirus, which includes a single species, mainly infects mustelids such as Lontra canadensis (Durden \& Musser 1994).

The seal louse Echinophthirius horridus was first described as Pediculus horridus by von Olfers (1816). Later descriptions resulted in a number of synonyms cited in the literature (Table 5). Lucas (1834) named the seal louse $P$. phocae, whereas Burmeister (1838) described it as $P$. setosus. Other scientific names that have been used are Haematopinus setosus (Denny 1842) and $H$. annulatus (Schilling \& Gurlt 1857). The genus Echinophthirius was first suggested by Giebel (1871), who used the name $H$. (Echinophthirius) setosus for the seal louse. All lice found on seals were first described as belonging to the genus Echinophthirius, i.e. E. setosus Piaget, 1880: Osborn (1896), Meinert (1897), Breddin (1901); E. groenlandicus Becher, 1886; E. sericans Meinert, 1897, until Enderlein (1904) named it E. phocae and described 2 new genera: the genus Lepidopthirus (1904) and Antarctophthirus (1906) within the suborder Anoplura. Enderlein (1906) mentioned that the genus Echinophthirius has setae all over the body, in contrast to Lepidopthirus and Antarctophthirus, which have leaf-like scales on dorsal or ventral sides of the thorax or the abdomen.

The seal louse was subsequently called Echinophthirius phocae by Enderlein (1904, 1906, 1909), von Dalla-Torres (1908), Luther (1909), Mjöberg (1910) and Evans (1913) until Fahrenholz (1919) finally named it E. horridus. A number of subspecies have been described in the past, but they have not been generally accepted. Ass (1935) suggested E. h. baikalensis for the seal louse on Baikal seals Phoca sibirica, Kurochkin \& Badamshin (1968) reported a louse E. h. caspicus on Caspian seals P. caspica, and Blagoveshtchensky (1966) named the louse found on bearded seals Erignathus barbatus as E. h. erignathi.

Both Freund (1928) and Jancke (1938) gave detailed descriptions of adult specimens of Echinophthirius horridus, and a more general description is given in the monograph by Ferris (1934). The first full description, including eggs and the 3 nymphal stages, was given by Scherf (1963a). More details of the developmental stages were observed using scanning electron micrographs of adult (Miller 1971) and nymphal stages of the louse (Beder 1990).

Eggs of Echinophthirius horridus resemble small barrels, with even bases and vaulted tops, and are laid in parallel with the hair of the host (Scherf 1963a). An egg is $0.928 \mathrm{~mm}$ long and $0.464 \mathrm{~mm}$ wide, covered with a brown attachment substance and divided into 7 to 11 chambers.

The 3 nymphal stages are distinguished by size differences. Nymphs undergo heterometabolic metamorphoses (Scherf 1963b): Stage 1 nymphs $\left(\mathrm{N}_{1}\right)$ are 1.12 to $1.13 \mathrm{~mm}$ long, Stage 2 nymphs $\left(\mathrm{N}_{2}\right)$ are 1.44 to $1.49 \mathrm{~mm}$ long and third stage nymphs $\left(\mathrm{N}_{3}\right)$ are 1.79 to $1.91 \mathrm{~mm}$ (Table 6).

The first nymphal stage has a stocky conical head, well distinguishable from the thorax (Scherf 1963a). All nymphs are eyeless, and the antennae have 4 segments like the adult stage (imago) (Fig. 4). The extremities are fully developed and increasingly sclerotisised from the tibiotarsus to the tip of the claw. The tibia carry small teeth (Scherf 1963a). For each nymphal stage the extremities become stronger, but show the same basic structures. Scherf (1963a) also described 1 to 2 ventral spines at the basal segment for the third nymphal stage. All nymphal stages have fewer setae than adults do, and numbers of setae increase with each nymphal stage (Scherf 1963a, Beder 1990). Sexual organs are first seen in $\mathrm{N}_{3}$, where a genital region is discernible at the ninth segment of the abdomen. The imago is reached after the third moult (Scherf 1963b).

Although there are remains of corneal structures (Freund 1928), the imago is eyeless, with a short and wide head (Ferris 1934, present paper Fig. 5). The rostrum is strong and well-developed, with various piercing structures used for sucking blood from the host (Scherf 1963b). The first and second segments of 
Table 6. Echinophthirius horridus. Number $(\mathrm{N})$ and mean total lengths $(\mathrm{mm})$ of the 3 nymphal stages of sucking lice

\begin{tabular}{|c|c|c|c|c|c|c|c|c|c|}
\hline \multirow{2}{*}{$\mathrm{N}$} & \multicolumn{2}{|c|}{ — Nymph $1-$} & \multirow[b]{2}{*}{$\mathrm{N}$} & \multicolumn{2}{|c|}{ - Nymph $2-$} & \multirow{2}{*}{$\mathrm{N}$} & \multicolumn{2}{|c|}{ - Nymph $3-$} & \multirow{2}{*}{ Source } \\
\hline & $\begin{array}{l}\text { Length } \\
\text { (mm) }\end{array}$ & $\begin{array}{l}\text { Min.-Max. } \\
\text { (mm) }\end{array}$ & & $\begin{array}{l}\text { Length } \\
\text { (mm) }\end{array}$ & $\begin{array}{l}\text { Min.-Max. } \\
\text { (mm) }\end{array}$ & & $\begin{array}{l}\text { Length } \\
(\mathrm{mm})\end{array}$ & $\begin{array}{l}\text { Min.-Max. } \\
\text { (mm) }\end{array}$ & \\
\hline 50 & 1.13 & $(0.97-1.25)$ & 50 & 1.49 & $(1.29-1.62)$ & 50 & 1.91 & $(1.74-2.15)$ & Scherf $(1963 a, b)$ \\
\hline 34 & 1.12 & $(0.78-1.38)$ & 42 & 1.44 & $(1.20-1.83)$ & 53 & 1.79 & $(1.58-2.13)$ & Beder (1990) \\
\hline
\end{tabular}

antennae show ventral lobes (Ferris 1934, Scherf 1963a,b, Miller 1971). While Freund (1928) and Scherf (1963a) mentioned sensilla basicornia on the terminal antennal segment, Miller (1971) described 2 such structures and 2 pore organs. The sensilla basicornia have 11 to 13 setae forming a ring. The head, thorax and abdomen of a louse are covered with numerous setae of variable lengths. In contrast to other taxa of lice, body spines are only developed in Echinophthirius (Kim 1985). The whole body, except for the corneal region (Freund 1928), is covered with setae
(Ferris 1934), but short stout setae are most common on the head (Kim et al. 1975) and on the ventral side of the thorax, whereas longer setae are more common on the abdomen (Miller 1971). Scales are totally absent in E. horridus (Freund 1928, Ferris 1934).

The thorax is small compared with the wide, nearly circular abdomen (Figs. 4 \& 5). The sternum has an irregular, sclerotic plate (Ferris 1934). Forelegs are smaller than the successively longer midlegs and hindlegs (Kim 1985). The femur carries most of the setae of the leg (Scherf 1963a). The caudal part of the climbing structure is enlarged, and the tibia and the tarsus are fused (Ferris 1934, Scherf 1963b), while the median tibiotarsus has a blunt appendix with 4 small pegs (Freund 1928). The claw has an obvious basal lobe (Ferris 1934).

The abdomen shows separated single segments, slightly furrowed, and is entirely membranous in both sexes except for the ninth tergum and the genital areas (Ferris 1934). The genital region is covered with long and slender setae (Miller 1971). Females lack dorsal setae, but have obvious ventral setae, whereas males have dorsal setae and obvious signs of a genital region on the ventral side of the abdomen (Scherf 1963a) (Fig. 6). Females carry 6 to 7 eggs of different stages of development in their abdomen, as described by Scherf $(1963 a, b)$. Females are somewhat longer (2.33 to $3.5 \mathrm{~mm})$ than males (2.12 to $3.0 \mathrm{~mm}$ ) (Table 7 ), but the sexes are otherwise quite similar (Ferris 1934, Scherf 1963a,b).

\section{Epidemiology}

\section{Distribution and host range}

Echinophthirius horridus is confined to northern phocid seals belonging to 4 genera and has been found on 9 species or subspecies. The presence on land-locked seal species in Lake Saimaa, Lake Baikal, and the Caspian Sea suggested that the relationship between lice and seals began at least before the freshwater species were separated by land barri-
Fig. 5. Echinophthirius horridus. Adult female in (A) dorsal and (B) ventral views (Scherf 1963a) 


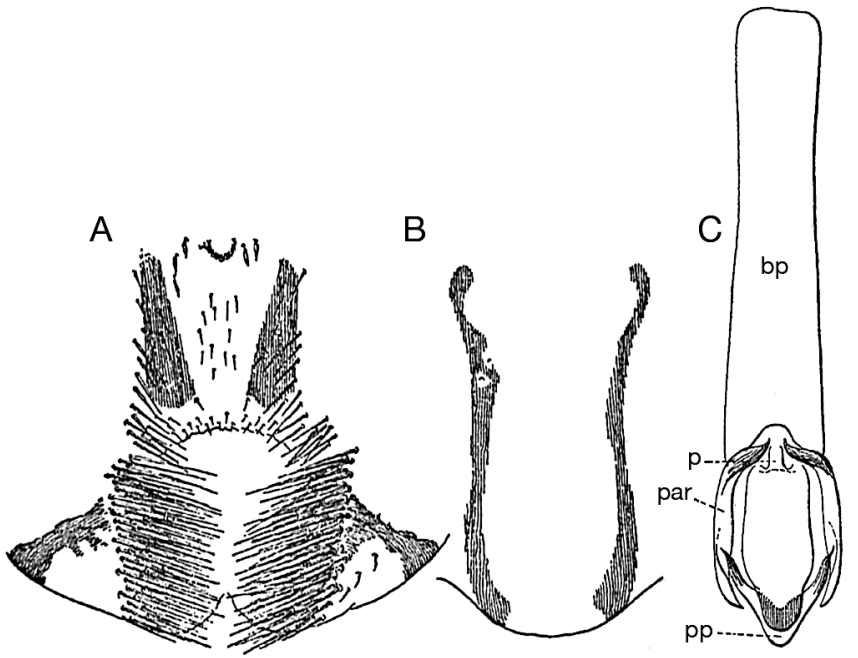

Fig. 6. Echinophthirius horridus. Genital regions: (A) female, (B) male and (C) genitalia of male. bp: basal plate; p: penis; par: parameres; pp: v-shaped pseudopenis (von Olfers 1816)

ers (Tijskens 1969). E. horridus is common on the harbour seals Phoca vitulina vitulina, $P$. V. concolor and $P$. v. richardii (Table 8) and is less frequently reported on Caspian seals (Kurochkin 1975), harp seals (Mjöberg 1910, Freund 1933, Ferris 1934, Hopkins 1949, Scherf 1963a, King 1964, Kim et al. 1975, Durden \& Musser 1994), ringed seals (Freund 1933, Ferris 1934, Hopkins 1949, King 1964, Mehl 1970, Miller 1971, Kim et al. 1975, Durden \& Musser 1994), the Saimaa ringed seals Phoca hispida saimensis (Luther 1909), Baikal seals P. sibirica (Freund 1928, Ass 1935, Scherf 1963a, King 1964, Kim et al. 1975, Durden \& Musser 1994), grey seals (Ferris 1934, Hopkins 1949, van den Broek \& Jansen 1964, King 1964, Bonner 1972, Kim et al. 1975, Durden \& Musser 1994, Kadulski 2001), bearded seals (Freund 1933, Hopkins 1949, King 1964, Blagoveshtchensky 1966, Kim et al. 1975, Durden \& Musser 1994) and hooded seals (Freund 1933, Hopkins 1949, King 1964, Kim et al. 1975, Durden \& Musser 1994) (Fig. 3).

Table 7. Echinophthirius horridus. Number (N) and mean total lengths (mm) of male and female lice. -: no data

\begin{tabular}{|c|c|c|c|c|c|c|}
\hline \multirow[b]{2}{*}{$\mathrm{N}$} & \multicolumn{2}{|c|}{ Males -} & \multirow[b]{2}{*}{$\mathrm{N}$} & \multicolumn{2}{|c|}{ Females } & \multirow{2}{*}{ Source } \\
\hline & $\begin{array}{l}\text { Length } \\
(\mathrm{mm})\end{array}$ & $\begin{array}{l}\text { Min.-Max. } \\
\text { (mm) }\end{array}$ & & $\begin{array}{l}\text { Length } \\
(\mathrm{mm})\end{array}$ & $\begin{array}{l}\text { Min.-Max. } \\
\text { (mm) }\end{array}$ & \\
\hline - & 1.9 & & - & 2.35 & & Piaget (1880) \\
\hline- & 3.0 & & - & 3.5 & & Ferris (1934) \\
\hline 50 & 2.36 & $(2.11-2.60)$ & 50 & 2.61 & $(2.34-3.03)$ & Scherf $(1963 a, b)$ \\
\hline 6 & $2.70-2.90$ & & 5 & $3.20-3.40$ & & Blagoveshtchensky (1966) \\
\hline- & & $(2.50-3.00)$ & & - & $(2.75-3.50)$ & Lauckner (1985) \\
\hline 150 & 2.12 & $(1.75-2.48)$ & 171 & 2.33 & $(1.70-2.92)$ & Beder (1990) \\
\hline 2 & - & & 2 & 2.71 & & Kadulski (2001) \\
\hline
\end{tabular}

Echinophthirius horridus occurs on harbour seals throughout Europe and on the Atlantic and Pacific coasts of Canada and the USA (Fig. 3). Only 3 quantitative studies have been carried out on louse abundance in harbour seals. The highest prevalence $(45.5 \%)$ was found in Washington (Dailey \& Fallace 1989), followed by $39.0 \%$ in northeast Scotland (Thompson et al. 1998) and 36.6\% in the Wadden Sea (Wipper 1974). In most other cases, only single animals have been examined or the lice burden is only mentioned vaguely in connection with general pathological investigations or health status reports (Table 8).

The seal louse is rarely found on healthy seals ( $T$. Härkönen unpubl. obs.), but is frequently reported on weak and especially young animals, which seem to be preferentially infected, because they are less resistant to diseases (Turner 1971, Geraci 1978, Reijnders et al. 1981, Lauckner 1985). Great numbers of lice have been reported on specimens from Norway (Mehl 1970), Scotland (Thompson et al. 1998), the Connecticut inlet, USA (Dunn \& Wolke 1976b), and from the coast of Florida (Caldwell \& Caldwell 1969). A young harbour seal from Danish waters was so heavily infected by lice that this was suspected to be the primary cause of death (Clausen 1978). Thompson et al. (1998) found the prevalence and intensity of lice infections to be greater in years when harbour seals were in poor condition. Weak and sick seals on the beach are sometimes infected with 1000s of lice. Massive infections have been documented on young seals in the Wadden Sea (Scherf 1963a, Schumann 1989) and the North Sea, where one seal had $>3$ lice $\mathrm{cm}^{-2}$ body surface (Lauckner 1985), and up to 51 lice $\mathrm{cm}^{-2}$ body surface have been reported from the coast of Virginia, USA (Conlogue et al. 1980).

Wipper (1974) reported heavy lice burdens mainly on yearlings ( $\mathrm{N}=27,7$ heavily infected animals), whereas adults $(\mathrm{N}=44)$ and pups $(\mathrm{N}=20)$ were less infected. Only one 4 mo old pup showed heavy infection. The quantitative study by Thompson et al. (1998) showed that only a few harbour seals carried high burdens (100s) of lice. The prevalence was low the first few months after birth, but increased when seals were older than 7 mo. Statistical analyses showed that age, season and year of investigation influenced the intensity of lice found on seals, whereby age and season had the strongest effects. Thompson et al. (1998) observed no seasonal variations for adults, but immature seals had higher prevalence of lice in spring. Contrastingly, Dailey \& Fallace (1989) found highest prevalence in autumn and winter, 
Table 8. Echinophthirius horridus. Reported occurrence of lice on harbour seals Phoca vitulina. M: mass burden/heavily infested; P: presence; A: absence. D: cause of seal death. C: captive; H: hunting; N: netting; O: observation; PDV: phocine distemper virus; S: stranded; -: no data

\begin{tabular}{|c|c|c|c|c|c|}
\hline $\begin{array}{l}\text { Subspecies } \\
\text { of } P \text {. } \\
\text { vitulina }\end{array}$ & Location & $\begin{array}{l}\text { Examined/ } \\
\text { infected } \\
\text { seals }\end{array}$ & $\begin{array}{l}\text { Lice } \\
\text { burden }\end{array}$ & $\mathrm{D}$ & Source \\
\hline \multirow[t]{18}{*}{ vitulina } & Europe & & & & \\
\hline & Denmark/Kattegat & $65 / 1$ & M & $\mathrm{H} / \mathrm{N} / \mathrm{S} / \mathrm{C}$ & Clausen (1978) \\
\hline & UK/Shetland Islands & - & $\mathrm{P}$ & - & Ferris $(1934)$ \\
\hline & UK/North Welsh coast & $1 / 1$ & M & $\mathrm{H}$ & Anderson et al. (1974) \\
\hline & UK/Moray Firth, Scotland & $223 / 87$ & $\mathrm{P}$ & $\mathrm{O}$ & Thompson et al. (1998) \\
\hline & Germany/North Sea Helgoland & $1 / 1$ & $\mathrm{P}$ & - & Mjöberg (1910) \\
\hline & Germany/North Sea Helgoland & $12 / 2$ & $\mathrm{P}$ & $\mathrm{S}$ & Vauk (1973) \\
\hline & Germany/Wadden Sea Sylt & $1 / 1$ & M & $\mathrm{H}$ & Scherf (1963a) \\
\hline & Germany/Wadden Sea Sylt & $43 / 11$ & $\mathrm{P}$ & PDV & Schumacher et al. (1990) \\
\hline & Germany/Wadden Sea & - & $\mathrm{P}$ & $\mathrm{O}$ & Essink et al. (2005) \\
\hline & Germany/Wadden Sea & $1 / 1$ & M & $\mathrm{O}$ & Schumann (1989) \\
\hline & Germany/Wadden Sea & $91 / 34$ & $\mathrm{P}$ & $\mathrm{H} / \mathrm{S}$ & Wipper (1974) \\
\hline & Iceland/Western part & - & $\mathrm{P}$ & $\mathrm{H}$ & Skirnisson \& Ólafsson (1990) \\
\hline & Netherlands/Texel & $2 / 1$ & $\mathrm{P}$ & $\mathrm{S}$ & Van den Broek \& Wensvoort (1959) \\
\hline & Netherlands/Wadden Sea & & $\mathrm{P}$ & $\mathrm{C}$ & Reijnders et al. (1981) \\
\hline & Norway & - & $\mathrm{P}$ & - & Mehl (1970) \\
\hline & Sweden/Kattegat-Skaggerak-Baltic & $158 / 0$ & A & PDV & Lunneryd (1992) \\
\hline & Sweden/Skagerrak & 2140 & $\mathrm{P}$ & $\mathrm{O}$ & T. Härkönen (unpubl. data) \\
\hline \multirow[t]{7}{*}{ concolor } & USA east/Canada & & & & \\
\hline & New Jersey coast & $1 / 1$ & $\mathrm{P}$ & $\mathrm{C}$ & Hoffmann et al. (2004) \\
\hline & Virginia coast & $1 / 1$ & M & $\mathrm{S}$ & Conlogue et al. (1980) \\
\hline & Nova Scotia/Sable Island & $15 / 15$ & $\mathrm{P}$ & $\mathrm{C}$ & McCelland (1980c) \\
\hline & Rhode Island/Connecticut & $3 / 1$ & M & $\mathrm{S} / \mathrm{C}$ & Dunn \& Wolke (1976b) \\
\hline & New England coast & 108 & $\mathrm{P}$ & $\mathrm{S} / \mathrm{O}$ & Geraci (1978) \\
\hline & Florida & $1 / 1$ & M & $\mathrm{S}$ & Caldwell \& Caldwell (1969) \\
\hline \multirow[t]{4}{*}{ richardii } & USA west & & & & \\
\hline & California/Los Angeles & $5 / 3$ & $\mathrm{P}$ & $\mathrm{C}$ & Brown et al. (1960) \\
\hline & Southern California & $5 / 3$ & $\mathrm{P}$ & $\mathrm{C}$ & Taylor et al. (1961) \\
\hline & Grays Harbor/Washington & $77 / 35$ & $\mathrm{P}$ & $\mathrm{C} / \mathrm{S}$ & Dailey \& Fallace (1989) \\
\hline
\end{tabular}

but no significant differences between examined age classes of seals and their lice burdens. The prevalence of lice differed strongly (20.0 to $81.8 \%$ ) among the 3 investigated years. The Wadden Sea Quality Status Report (Essink et al. 2005) documented a decline in occurrence of the seal louse on Phoca vitulina vitulina from approximately $15 \%$ in the early 1980s down to $1.5 \%$ around 2000 . Thus, seal louse populations seem to be influenced both by many biotic (e.g. age and body condition of the host) and abiotic factors (e.g. temperature).

The prevalence of lice (Antarctophthirius callorhini and Proechinophthirius fluctus) in the pelage and on the skin of northern fur seals was highest on pups of the year and decreased with the age of the host, and more adult females than males were infected (Kim 1972, 1975). It has been suggested that the higher prevalence in pups is linked to a higher body temperature, thinner dermis, thinner blubber/panniculus adiposus and thinner pelage structure compared with adults (Kim 1975). Additionally, pups spend more time on shore, where transmission is possible.
Clinical signs and pathology

Lice do not normally cause severe pathological changes, but infected patches of skin often show alopecia and skin irritations (Colongue et al. 1980, Raga 1992, Dailey 2001). However, large numbers of lice on a seal can weaken the host, and thereby increase the risk of other parasite or bacterial infections, or lead to severe anaemia (Turner 1971, Sweeney 1978, Lauckner 1985, Dailey 2001). Thompson et al. (1998) reported no significant differences in haematological parameters of infected and non-infected seals, but a significant negative correlation between number of lice on infected seals and their total erythrocyte count, haematocrit and haemoglobin concentration. Consequently, high burdens of lice can impair the diving ability of seals (Thompson et al. 1998).

\section{Microhabitat: adaptation to the marine environment}

The fact that lice (suborder Anoplura) belong to the class Insecta and have adapted to the marine environ- 
ment is an example of a rare evolutionary event, since few insects have been able to adjust in order to cope with the marine environment. Contrastingly, whalelice such as Cyamus (Cyamidae), which suck blood and destroy the tissue of whales, are not insects but amphipods (Crustacea). Insect parasites on marine hosts require adaptations such as a reservoir of air and an ability to adjust movements and life cycles to the diving pattern of the host (Tijskens 1969). The extremities of the seal louse are strongly built in all developmental stages compared to the rest of the body, and increasingly sclerotisised in each developmental stage (Scherf 1963a). Claws are blunt (Kim et al. 1975) and extremely strong (Mjöberg 1910). Scherf (1963a) gave a detailed description of how the tibiotarsus was adapted to cling on to the fur of the host.

Echinophthirius horridus spends its entire life on the seal host (from egg to nymph to imago). Seals can be submerged up to $80 \%$ of the time, depending on the seasonal activity patterns of the seal (Teilmann et al. 1999). Consequently, access to air could be a factor limiting survival and reproduction in E. horridus. Female lice are suggested to lay eggs only when the host is on land (Scherf 1963b). However, there could be some differences between the genera Echinophthirius, Antarctophirus and Lepidophthirus in this respect. Echinophthirius is mainly found on the head and neck of phocid seals (Lucas 1834, Luther 1909, Mjöberg 1910, Caldwell \& Caldwell 1969, Bonner 1972, Wipper 1974, Geraci 1978, Conlogue et al. 1980, Reijnders et al. 1981, Kadulski 2001), especially near the snout (Lucas 1834, Luther 1909, Skirnisson \& Ólafsson 1990), but also on the ventrolateral region of the posterior part of the stomach (Caldwell \& Caldwell 1969), on the back (Luther 1909), around the tail (Reijnders et al. 1981), on the caudal back including the hind flipper (Mohr 1952, Wipper 1974), around the anus (Bonner 1972), on the sacral and genital region, on the femoral region of the flipper (Conlogue et al. 1980), on the hind flipper (Mjöberg 1910), and on the dorsal surface of the hind flipper (Thompson et al. 1998). E. horridus is suggested to prefer skin areas, which the host cannot reach (Mohr 1952).

In contrast, species of the genera Antarctophthirus and Lepidophthirus found on Otariidae, Odobenidae and Monarchinae are not observed in the head region of seals, but on other parts of the body (Enderlein 1906): the hind flippers (Murray 1958, Murray \& Nicholls 1965, Murray et al. 1965, Kim 1975, Mehlhorn et al. 2002), the fore flippers (Murray \& Nicholls 1965, Murray et al. 1965, Kim 1972), the tail, ankle and hip (Murray et al. 1965), the nostrils, auditory canal, eyelids and umbilical area (Kim 1972) and around anal and penile orifices (Murray et al. 1965, Kim 1972).

Enderlein (1906) suggested that the region where lice live on the seals, as well as the existence of either setae (Echinophthirius) or leaf-like scales (Antarctophthirus and Lepidophthirus), are adaptations of the lice to their habitats. E. horridus mainly prefer the head region, which is the part of the body most frequently exposed to air in the phocid seals they infect, whereas species of Antarctophthirus also live on other parts of the seal's body. Enderlein (1906) also suggested that the leaf-like scales covering the body of Antarctophthirus have the physiological property of keeping an air reservoir when submerged. Diving experiments with adults and nymphs of E. horridus show that the hydrophilic cuticula of E. horridus cannot store air, so they must use the air trapped in the fur of their hosts during diving periods (Messner et al. 1998). The fact that E. horridus becomes immobilised as soon as it is submerged reveals the difficulties insects have in adjusting to a marine existence, and that seal lice cannot be termed plastrons, since true plastrons maintain their ability to move (Messner et al. 1998). Whereas the louse species Lepidophthirus macrorhini is more morphologically adapted to the marine environment (e.g. leaf-like scales), E. horridus has a behavioural adaptation (e.g. to occur near the nose or head region during diving periods of the seal).

\section{Transmission patterns}

Transmission of lice from one seal to another is only possible when seals are hauled-out on land or on ice (Kim 1975). Mechanisms and opportunities for lice to spread are likely to differ among genera and are obviously affected by the haul-out substrate of the host, since weaned pups of seals are heavily infected in the Arctic and Antarctic (Murray \& Nicholls 1965, Murray et al. 1965, Kim 1972, 1975), which is rarely seen in harbour seals (Thompson et al. 1998). The life cycles of Antarctic lice are completed within 17 to $28 \mathrm{~d}$, but are shorter in warmer air (Murray \& Nicholls 1965, Murray et al. 1965, Kim 1975). There is no information about the duration of the life cycle of Echinophthirius horridus, but it is suggested to be longer than those of Antarctic lice, since only low numbers of lice are found on adult females and weaned pups (Thompson et al. 1998).

For Arctic and Antarctic lice species the major transmission occurs from females to pups during nursing, since pups are infected 7 to $12 \mathrm{~h}$ after birth (Kim 1972). Pup-to-pup transmission also seems to be important in species where pups form close congregations (Kim 1972), whereas transmission among adults may play a minor role since lice densities are low in adults (Kim 1975).

The transmission of Echinophthirius horridus is suggested to differ from the patterns shown for Arctic and 
Antarctic lice species. Thompson et al. (1998) suggested the possibility that lice must travel several metres to find their next host in herds of seals or, alternatively, that lice can survive some time without a host until a new host appears at the haul-out site. Movements of lice can be triggered by a decreasing host body temperature (Kim 1972), because lice always abandon their hosts at rigor mortis (Mjöberg 1910), but lice may not to be able to survive for significant periods without a host (Scherf 1963b). Lunneryd (1992) could not find any lice, although the prevalence of Acanthocheilonema spirocauda was $18 \%$ in harbour seal samples from the Kattegat-Skagerrak and lice have been observed on seals from this area (T. Härkönen unpubl. data) (Table 6). The total absence of lice in this region reported in earlier studies was suggested to be a consequence of lice having left their hosts before carcasses were recovered (Thompson et al. 1998).

Also, the different haul-out substrates used by seals (sand banks, mud pools, rocks) seem to affect the dispersal of lice. While Wipper (1974) recorded low numbers of lice at haul-out patches of harbour seals on sand banks, Murray \& Nicholls (1965) could not observe transmission of lice among seals moulting in mud pools. The period adult pinnipeds spend in mud pools or ashore during moulting time seems to be a limiting factor for the survival of lice (Murray \& Nicholls 1965, Kim et al. 1975).

\section{THE SEAL LOUSE AS INTERMEDIATE VECTOR OF THE HEARTWORM}

Lice are well-known vectors of serious diseases in terrestrial mammals, e.g. Rickettsia prowazekii, which causes epidemic typhus in humans (Hase 1931). Studies on lice-borne pathogens are scarce from the marine environment, but seal lice could potentially be important for spreading epidemic viral or bacterial diseases in seals. However, the only example of this to date is Salmonella enteritidis isolated in tissue of lice found on 5 infected fur seal pups at the Pribilof Islands (Jellison \& Milner 1958).

Species within the genus Acanthocheilonema use several vectors, such as fleas, ticks, or sucking lice for transmission among terrestrial hosts (Anderson 2000). Wülker (1930) was the first to suggest Echinophthirius horridus could play an important role in the transmission of A. spirocauda in seals, but found no evidence of $\mathrm{mf}$ in lice. The coincidence of simultaneous occurrence of E. horridus on seals and A. spirocauda in the heart of seals led several investigators to support this hypothesis (e.g. Mohr 1952). Several studies have attempted to find intermediate stages of A. spirocauda in E. horridus (Taylor et al. 1961, Dunne \& Wolke 1976b, Mehlhorn et al. 2002). However, since no evidence of filariae appeared, some investigators instead suggested other intermediate hosts, such as simuliids and mosquitoes that are often observed around hauled out seals (Taylor et al. 1961). This suggestion seems plausible since well-known heartworm species, such as Dirofilaria immitis, infecting dogs and cats, cannot mature into adult worms without first passing through a mosquito (Anderson 2001).

The only current conclusive evidence of filariae of Acanthocheilonema spirocauda in Echinophthirius horridus was provided by Geraci et al. (1981), who dissected 102 lice collected from a stranded harbour seal held in captivity. Seventy lice were infected with different stages of $A$. spirocauda, and they found an average of 4.6 first-stage larvae per louse in $87 \%$ of all infected lice, an average of 1.4 second-stage larvae per louse in $26 \%$ of infected lice, and an average of 3.0 third-stage larvae per louse in $54 \%$ of the infected lice. The larvae were mainly found in the fat body of the louse, but also in the gut, haemocoel, claws and head. The mf found in the gut were not distinguishable from those found in the blood of the seals. Consequently, the first 3 larval stages seem to develop in the louse, after which third-stage larvae are transmitted back to the final host (Fig. 7). The fourth-stage larvae will develop in the blood system of seals and eventually transform to the adult stage (Raga 1992). Dunn \& Wolke (1976b) suggested that $A$. spirocauda reach sexual maturity within 6 mo or less, because they found $\mathrm{mf}$ in the blood of young 8 mo old harbour seals. Adult worms seem to mature in the heart, where females shed $\mathrm{mf}$ into the blood stream, and these are subsequently transmitted to sucking lice. Geraci et al. (1981) noted the rarity of sucking lice serving as vectors of filariid worms, because there is only one additional known example: the canine louse Linognathus setosus, which serves as an intermediate host for $A$. reconditum infecting dogs (Pennington \& Phelps 1969).

That the seal louse acts as an intermediate host of the heartworm is also supported by the significant correlation between the occurrence of Acanthocheilonema spirocauda and Echinophthirius horridus on seals in Washington State, USA (Dailey \& Fallace 1989). Although E. horridus is the main candidate as an intermediate host of $A$. spirocauda, this has yet to be verified experimentally. The heartworm life cycle (Fig. 7) illustrates the possible transmission of $A$. spirocauda through sucking lice from seal to seal. A transplacental transmission of $\mathrm{mf}$ has been described for Dirofilaria immitis (Todd \& Howland 1983) and D. repens in dogs (Guarda \& Mandelli 1996). In general, transplacental passage of $\mathrm{mf}$ is possible (Loke 1982), but seems to be relatively rare. In a study encompassing $22 \mathrm{mf}$-positive mothers of Wuchereria bancrofti in Haiti, only 2 pla- 
Fig. 7. Acanthocheilonema spirocauda in Phoca vitulina and Echinophtirius horridus. Possible life cycle and transmission routes of heartworms in harbour seal and seal louse. L1-4: first to fourth stage larvae; L4?: no detailed descriptions as yet available

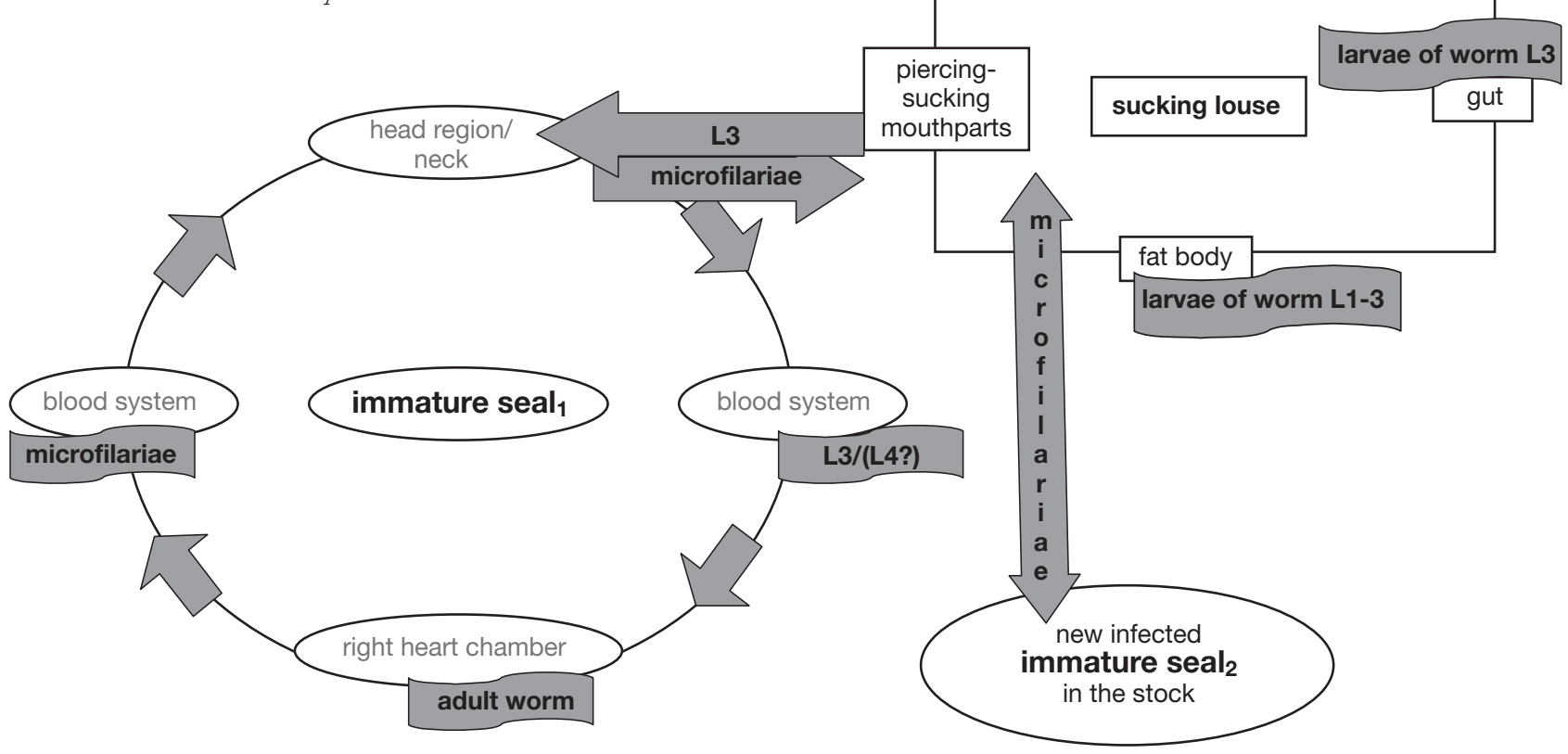

centas were infected with mf (Eberhard et al. 1993). To date, there have been no observations of the 3 first larval stages of heartworms in seals. The only observation of mf in 8 mo old pups (Dunn \& Wolke 1976b) could be a result of transplacental transmission as well as the first generation of mature worms. Sweeney (1973) reported A. spirocauda in 4 of 13 examined pups, all $<3$ mo. However, the author did not give details about the developmental stage (mf or larvae), but it was taken as evidence for transplacental transmission (Sweeney 1973). Nevertheless, this form of transmission cannot be the main mechanism, since heartworms are much rarer in adult seals compared with juveniles.

In contrast to terrestrial mammals, there is a predominance of heteroxenous forms of parasitic nematodes in marine mammals, using intermediate hosts for transmission (Anderson 1984). Lack of effective swimming stages (such as kinocilia) in aquatic parasitic nematodes means that the dispersal routes of Acanthocheilonema spirocauda are limited by the behaviour of its hosts. The seal louse Echinophthirius horridus likely became a paratenic host of heartworms, and as the louse became more specialised, A. spirocauda is suggested to have adapted its dispersal to the behaviour of the ancestors of the seals (Anderson 1984).

Due to the limited evidence of mf and larval stages in Echinophthirius horridus, it cannot be ruled out that alternative intermediate hosts such as mosquitoes or simuliids could play an important role in the dispersal of Acanthocheilonema spirocauda among seals. Heartworms infecting dogs in terrestrial environments and phocid seals in the marine environment are good examples of adaptations among parasites (Ménier 2000). Both heartworms show high pathogenic rates and have similar clinical signs that often end with the death of the host. The fact that Dirofilaria immitis has been observed several times in California sea lions (Forrester et al. 1973, Howard et al. 1983, Sato et al. 2002), supports the idea that the 2 heartworms share the ancestor Canoidea.

Acknowledgements. We are grateful to Mrs. M. Fetting, Mrs. G. Rasch and Mrs. E. Stubel for translations of documents in French, Russian and Polish. This manuscript benefited from the comments of 2 unknown reviewers and the editors.

\section{LITERATURE CITED}

Anderson RC (1959) The taxonomy of Dipetalonema spirocauda (Leidy, 1858) n. comb. (= Skrjabinaria spirocauda) and Dirofilaria roemieri (Linstow, 1905) n. comb. (= Dipetalonema roemeri). Can J Zool 37:481-493

Anderson RC (1984) The origins of zooparasitic nematodes. Can J Zool 62:317-328

Anderson RC (1992) Nematode parasites of vertebrates: their development and transmission, 1st edn. CAB International, Wallingford

Anderson RC (2000) Nematode parasites of vertebrates: their development and transmission, 2nd edn. CAB International, Wallingford 
Anderson RC (2001) Filaroid nematodes. In: Samuel WM, Pybus AA (eds) Parasitic diseases of wild mammals. Iowa State University Press, Ames, IA, p 342-356

Anderson RC, Bain O (1976) Keys to the genera of the order Spirurida. Part 3. Diplotriaenoidea, Aproctoidea and Filarioidea. In: Anderson RC, Chabaud AG, Willmott S (eds) $\mathrm{CIH}$ keys to the nematode parasites of vertebrates. $\mathrm{CAB}$ International, Wallingford, p 59-116

Anderson SS, Bonner WN, Baker JR, Richards R (1974) Grey seals, Halichoerus grypus, of the Dee estuary and observations on a characteristic skin lesion in British seals. J Zool 174:429-440

Arnason U, Gullberg A, Janke A, Kullberg M, Lehman N, Petrov EA, Väinölä R (2006) Pinniped phylogeny and a new hypothesis for their origin and dispersal. Mol Phylogenet Evol 41:345-354

Ass MI (1935) Ectoparasites of the Baikalian seal. Tr Baik Limnol St Acad Sci USSR 6:10-45

Bain O, Baker M, Chabaud AG (1982) Nouvelles données sur la lignée Dipetalonema (Filarioidea, Nematoda). Ann Parasitol 57:593-620

Becher E (1886) Insecten von Jan Mayen. Int Polarforsch 1882-1883 3:59-66

Beder G (1990) Rasterelektronmikroskopische Studie der Robbenlaus Echinophthiridus horridus (Olfers, 1816). Mitt Dtsch Ges Allg Angew Entomol 7(4-6):512-516

Blagoveshtchensky DI (1966) New forms of lice (Siphunculata) parasites of pinnipeds and hares. Entomol Obozr 45: 806-813

Bonner WN (1972) The grey seal and common seal in European waters. Oceanogr Mar Biol Annu Rev 10:461-507

Borgsteede FHM, Bus HGJ, Verplanke JAW, van der Burg WPJ (1991) Endoparasitic helminths of the harbour seal, Phoca vitulina, in the Netherlands. Neth J Sea Res 28(3):247-250

Brattey J, Stenson GB (1993) Host specificity and abundance of parasitic nematodes (Ascaridoidea) from the stomachs of five phocid species from Newfoundland and Labrador. Can J Zool 71:2156-2166

Breddin G (1901) Die Hemipteren und Siphunculaten des arktischen Gebietes. Fauna Arct 2:531-560

Breuer EM, Hofmeister R, Ernst R, Hörchner F, Höppner I (1988) Untersuchungen zum Seehundsterben im Wattenmeer vor Sylt 1988: Bedeutung des hochgradigen Lungenwurmbefalls mit hypersensitiver Reaktion. J Vet Med Ser B 35:467-473

Brown DH, McIntyre RW, Delli Quadri CA, Schröder RJ (1960) Health problems of captive dolphins and seals. J Am Vet Med Assoc 137:534-538

Burmeister H (1838) Genera Insectorum, Vol 1. Rhynchota. Continent tabulas XL. Burmeister, Berlin

Caldwell DK, Caldwell MC (1969) The harbor seal, Phoca vitulina concolor, in Florida. J Mamm 50(2):379-380

Casiraghi M, Bazzocchi C, Mortarino M, Ottina E, Genchi C (2006) A simple molecular method for discriminating common filarial nematodes of dogs (Canis familiaris). Vet Parasitol 141:368-372

Chabaud AG (1952) Le genre Dipetalonema Diesing, 1861; essai de classification. Ann Parasit Hum Comp 27:250-285

Clausen B (1978) Diseases and toxochemicals in the common seal in Denmark. Riistatiet Julk 37:38-39

Claussen D, Strauss V, Ising S, Jäger M, Schnieder T, Stoye M (1991) The helminth fauna from the common seal (Phoca vitulina vitulina Linnè, 1758) of the Wadden Sea in Lower Saxony. Part 2. Nematodes. J Vet Med Ser B 38:649-656

Conlogue GJ, Ogden JA, Foreyt WJ (1980) Pediculosis and severe heartworm infection in a harbor seal. Vet Med Small Anim Clin 75(7):1184-1187
Dailey MD (1975) The distribution and interspecific variation of helminth parasites in pinnipeds. Rapp P-V Reun Cons Int Explor Mer 169:338-352

Dailey MD (1978) Parasitology: basic considerations. In: Fowler ME, Saunders WB (eds) Zoo and wild animal medicine. WB Saunders, Philadelphia, PA, p 592-596

Dailey MD (2001) Parasitic diseases. In: Dierauf LA, Gulland MD (eds) CRC handbook of marine mammal medicine. CRC Press, Boca Raton, FL, p 357-379

Dailey MD, Fallace LS (1989) Prevalence of parasites in a wild population of the Pacific harbour seal (Phoca vitulina richardsi) from Gray's Harbor, Washington. Bull South Calif Acad Sci 88(1):1-10

Delamure SL, Popov VN (1974) On seasonal variations in the fauna of helminths of the Okhotsk ringed seals. Parazitologiya 8(2):89-92

Delamure SL, Treshchev VV (1966) On the helminth fauna of Cystophora cristata Erxleben dwelling in the Greenland Sea. Zool Zh 45:1867-1871

Delamure SL, Yurakhno MV, Popov VN (1976) On the helminth fauna of pinnipeds from the Karaginsk Gulf (the Bering Sea). Parazitologiya 10(4):325-332

Denny H (1842) Monographia Anoplurorum Britanniae XXIV:262. Bohn, London, p 1-36

Dierauf LA (2000) Marine mammal parasitology. In: Dierauf LA (ed) Handbook of marine mammal medicine: health, diseases and rehabilitation. CRC Press, Boca Raton, FL, p 89-96

Dunn JL, Wolke RE (1976a) Phocid heartworm, Dipetalonema spirocauda, infections of the Atlantic harbor seal (Phoca vitulina concolor). Aquat Mamm 4:59 (abstract)

Dunn JL, Wolke RE (1976b) Dipetalonema spirocauda infection in the Atlantic harbor seal (Phoca vitulina concolor). J Wildl Dis 12:531-538

Dunn LA, Spotte S (1974) Some clinical aspects of seal pox in captive Atlantic harbor seals. J Zoo Anim Med 5:27-30

Durden LA, Musser GG (1994) The sucking lice (Insecta, Anoplura) of the world: a taxonomic checklist with records of mammalian hosts and geographical distributions. Bull Am Mus Nat Hist 218:1-90

Eberhard ML, Hitch WL, McNeeley DF, Lammie PJ (1993) Transplacental transmission of Wuchereria bancrofti in Haitian women. J Parasitol 79(1):62-66

Eley TJ (1981) Dipetalonema spirocauda in Alaskan marine mammals. J Wildl Dis 17(1):65-67

Enderlein G (1904) Läusestudien. Über die Morphologie, Klassifikation und systematische Stellung der Anopluren nebst Bemerkungen zur Systematik der Insektenordnungen. Zool Anz 28:121-147

Enderlein G (1906) Läusestudien. V. Schuppen als sekundäre Atmungsorgane, sowie über eine neue antarktische Echinophthiriiden-Gattung. Zool Anz 29:659-665

Enderlein G (1909) Monographie der Robbenläuse. In: Enderlein G (ed) Die Insekten des Antarktischen Gebietes. Dtsch Südpol Exped 2:505-516

Essink K, Dettmann C, Farke H, Laursen K, Lüerßen G, Marencic H, Wiersinga W (eds) (2005) Wadden Sea quality status report 2004. Wadden Sea Ecosystem No. 19, Trilateral Monitoring and Assessment Group, Common Wadden Sea Secretariat, Wilhelmshaven

Estacio RH, Dy EER, Cresswell S, Coronel RF, Alora AT (1993) The quantitative buff coat technique (QBC) in early diagnosis of malaria: the Santo Tomas University Hospital experiences. Philos J Microbiol Infect Dis 22(2): 56-59

Evans (1913) Echinophthirius phocae (Lucas). Proc R Soc Edinb B 19:95 
Fahrenholz H (1919) Zur Nomenklatur einiger Anoplurenarten. II. 5-10 Jahrb (Niedersächs Zool Ver) Naturhis Ges Hannover, p 22-27

Ferris GF (1934) Contributions toward a monograph of the sucking lice. Part VII. Biol Sci 2(7):471-526

Forrester DJ, Jackson RF, Miller JF, Townsed BC (1973) Heartworm in captive California sea lions. J Am Vet Med Assoc 163:568-573

Freund L (1928) Anoplura Pinnipediorum (Robbenläuse). In: Grimpe G, Wagler E (eds) Tierwelt der Nord- und Ostsee, Vol 4 (11). Geest und Portig, Leipzig, p 1-36

Freund L (1933) Pinnipedia. In: Grimpe G, Wagler E (eds) Tierwelt der Nord- und Ostsee, Vol 2 (12). Geest und Portig, Leipzig, p 1-37

Geraci JR (1978) The enigma of marine mammal strandings. Oceanus 21:38-47

Geraci JR, Aubin DJSt (1986) Effects of parasites on marine mammals. Int J Parasitol 17:407-414

Geraci JR, Fortin JF, Aubin DJ St, Hicks BD (1981) The seal louse, Echinophthirius horridus: an intermediate host of the seal heartworm, Dipetalonema spirocauda (Nematoda). Can J Zool 59:1457-1459

Giebel C (1871) Analytische Übersicht der Säugetierläuse, Haematopinus und Trichodectes. Z Ges Naturw Ser 2/3: 173-179

Goltsev VN, Yurakhno MV, Popov VN (1978) About the locality of the Karaga and Anadyr population of Phoca vitulina largha. Zool Zh 57(2):280-287

Gosselin JF, Measures LN, Huot J (1998) Lungworm (Nematoda: Metastrongyloidea) infections in Canadian phocids. Can J Fish Aquat Sci 55:825-834

Guarda F, Mandelli G (1996) Trattato di anatomia patologica veterinaria. UTET, Torino, p 49

Gulland FMD, Haulena M, Dierauf LA (2001) Seals and seal lions. In: Dierauf LA, Gulland MD (eds) CRC handbook of marine mammal medicine. CRC Press, Boca Raton, FL, p 907-926

Hase A (1931) Siphunculata; Anoplura; Aptera. Läuse. In: Schulze K (ed) Biologie der Tiere Deutschlands, Part 30. Borntraeger, Berlin, p 1-58

Helle O, Blix AS (1973) Some morphological characteristics of Dipetalonema spirocauda Leidy, 1858, isolated from the hooded seal, Cystophora cristata Exleben, 1777. J Parasitol 59:217-218

Hoffmann V, Nolan TJ, Schoelkopf R (2004) First report of the giant kidney worm (Dioctophyme renale) in a harbor seal (Phoca vitulina). J Parasitol 90(3):659-660

Hopkins GHE (1949) Host associates of the lice of mammals. Proc Zool Soc 119:387-604

Howard EB, Britt JO, Matsumoto G (1983) Parasitic diseases. In: Howard EB (ed) Pathobiology of marine mammal diseases, Vol I. CRC Press, Boca Raton, FL, p 119-232

Jancke O (1938) Die Anopluren Deutschlands. In: Dahl F (ed) Die Tierwelt Deutschlands, 6. Fisher, Jena, p 75-76

Jellison WL, Milner KC (1958) Salmonellosis (bacillary dysentery) of fur seals. J Wildl Manag 22:199-200

Joly N (1859) Sur une nouvelle esèce d'hématozoaire du genre Filaria (Filaria cordis phocae N. Joly), trouvé dans le cœur d'un phoque. Mem Acad Sci Toulouse 2:166-180

Kadulski S (2001) Echinophthirius horridus (Olfers, 1816) (Anoplura) rare parasite on seals. Wiad Parazytol 47(3):269-271

Kennedy S, Smyth JA, Cush PF, Duignan P, Platten M, McCullough SJ, Allan GM (1989) Histopathologic and immunocytochemical studies of distemper in seals. Vet Pathol 26:97-103

Kim KC (1972) Louse populations of the northern fur seal (Callorhinus ursinus). Am J Vet Res 33:2027-2036
Kim KC (1975) Ecology and morphological adaptation of the sucking lice (Anoplura: Echinophthiriidae) on the northern fur seal. Rapp P-V Réun Cons Int Explor Mer 169:504-515

Kim KC (1985) Evolution and host associations of Anoplura. In: Kim KC (ed) Coevolution of parasitic arthropods and mammals. John Wiley and Sons, New York, p 197-231

Kim KC, Repenning CA, Morejohn GV (1975) Specific antiquity of the sucking lice and evolution of otariid seals. Rapp P-V Réun Cons int Explor Mer 169:544-549

King JE (1964) Seals of the world. British Museum (Natural History), London, p 134-140

Klimpel S, Palm HW, Rückert S, Piatkowski U (2004) The life cycle of Anisakis simplex in the Norwegian Deep (northern North Sea). Parasitol Res 94:1-9

Kreis HA (1953) Beiträge zur Kenntnis parasitischer Nematoden. XIII. Skrjabinaria heteromorpha n. sp. (Filarioidea Weinland, 1858; Stiles, 1907) aus dem Seehund (Phoca vitulina L). Mitt Zool Garten Leipzig 20:108-113

Kulu DD (1972) Evolution and cytogenetics. In: Ridgway SE (ed) Mammals of the sea-biology and medicine. Thomas, Springfield, IL, p 517-527

Kurochkin YV (1975) Parasites of the Caspian seal Pusa caspica. Rapp P-V Réun Cons Int Explor Mer 169:363-365

Kurochkin YV, Badamshin BI (1968) Finding of the seal lice Echinophthirius horridus Olfers, 1816 on the Caspian seal and the problem of origin of its parasite fauna. Tr Astrakh Zapoved 11:199-208

Lai CH, Tung KC, Ooi HK, Wang JS (2000) Competence of Aedes albopictus and Culex quinquefasciatus as vector of Dirofilaria immitis after blood meal with different microfilarial density. Vet Parasitol 90:231-237

Lauckner G (1985) Diseases of Mammalia: Pinnipedia. In: Kinne O (ed) Diseases of marine animals, Vol 4(2). Biologische Anstalt Helgoland, Hamburg, p 683-793

Leidy J (1858) Contributions to helminthology. Proc Acad Nat Sci Phila 10:110-112

Loke YW (1982) Transmission of parasites across the placenta. Adv Parasitol 21:155-228

Lubimov MP (1927) Concerning filariae found in the animals of the zoopark of Moscow. Tr Lab Eksper Biol Mosk Zooparka 3:295-311

Lucas H (1834) Pediculus phocae. Magas Zool 4:120-122

Lunneryd SG (1992) Dipetalonema spirocauda (Leidy) (Nematoda) and Corynosoma strumosum (Rudolphi) (Acanthocephala) infection in harbour seal from the KattegatSkagerrak and the Baltic. Sarsia 76:267-271

Luther A (1909) Über Echinophthirius phocae (Luc.) als Parasit der Saima-Robbe (Phoca foetida v. saimensis Nordquv.). Medd Soc Fauna Flora Fenn 36:17-19

MacDonald DW, Gilchrist EW (1969) Dipetalonema spirocauda and Pseudomonas aeruginosa infection in a harbor seal (Phoca vitulina). Can Vet J 10(8):220-221

Machida M (1977) Two species of Dipetalonema from pinnipeds caught off northern Japan. Bull Nat Sci Mus (Tokyo) $3(2): 67-71$

McCelland G (1980a) Phocanema decipiens: molting in seals. Exp Parasitol 49:128-136

McCelland G (1980b) Phocanema decipiens: growth, reproduction, and survival in seals. Exp Parasitol 49:175-187

McCelland G (1980c) Phocanema decipiens: pathology in seals. Exp Parasitol 49:405-419

McCelland G (1982) Phocanema decipiens (Nematoda: Anisakinae): experimental infections in marine copepods. Can J Zool 60:502-509

McCelland G (2002) The trouble with sealworms (Pseudoterranova decipiens species complex, Nematoda): a review. Parasitology 124:183-203 
Measures LN (2001) Lungworms of marine mammals. In: Samuel WM, Pybus AA (eds) Parasitic diseases of wild mammals. Iowa State University Press, Ames, IA, p 279-300

Measures LN, Gosselin J-F (1994) Helminth parasites of ringed seal, Phoca hispida from northern Quebec, Canada. J Helminthol Soc Wash 61(2):240-244

Measures LN, Gosselin JF, Bergeron E (1997) Heartworm, Acanthocheilonema spirocauda (Leidy, 1858), infections in Canadian phocid seals. Can J Fish Aquat Sci 54: 842-846

Mehl R (1970) Records of ectoparasitic insects and mites on birds and mammals in Norway. Norsk Entomol Tidsskr 17(2):109-113

Mehlhorn B, Mehlhorn H, Plötz J (2002) Light and scanning electron microscopical study on Antarctophthirus ogmorphini lice from the Antarctic seal Leptonychotes weddelli. Parasitol Res 88:651-660

Meinert F (1897) Neuroptera, Pseudoneuroptera, Thysanopoda, Mallophaga, Collembola, Suctoria, Siphunculata Groenlandica. Vidensk Medd Nathist Foren Kjöbenh 5:154- 177

Ménier K (2000) Origine et évolution du parasitisme chez les mammifères marins: l'exemple des «Pinnipèdes». Rev Méd Vét 151(4):275-280

Menschel E, Kraft H, Schiefer B (1966) Lungenwurmbefall bei wildlebenden Seehunden (Phoca vitulina L). Berl Muench Tieraerztl Wochenschr 17:333-337

Messner B, Trei H, Rabenstein F (1998) Ist die Seehundlaus ein Plastronatmer? Zur Atmung der Seehundlaus Echinophthirius horridus (Olfers, 1816) (Echinophthiriidae, Anoplura). Drosera 98(1):11-18

Miller FH (1971) Scanning electron microscopy of Echinophthirius horridus (von Olfers), Antarctophthirus callorhini (Osborn), and Proechinophthirius fluctus (Ferris) with emphasis on the antennal structures (Anoplura: Echinophthiriidae). J Parasitol 57(3):668-674

Mjöberg E (1910) Studien über Mallophagen und Anopluren. Ark Zool 6(13):1-296

Mohr E (1952) Die Robben der Europäischen Gewässer. Schöps, Frankfurt am Main

Murray MD (1958) Ecology of the louse Lepidophthirius macrorhini Enderlein, 1904 on the elephant seal Mirounga leonine (L). Nature 182:404-405

Murray MD, Nicholls DG (1965) Studies of the ectoparasites of seals and penguins. 1. The ecology of the louse Lepidophthirius macrorhini Enderlein on the southern elephant seal, Mirounga leonina (L). Aust J Zool 13:437-454

Murray MD, Smith MSR, Soucek Z (1965) Studies of the ectoparasites of seals and penguins. 2. The ecology of the louse Antarctophthirius ogmorphini Enderlein on the Weddell seal, Leptonychotes weddelli Lesson. Aust J Zool 13:761-771

Nagasawa K (1999) Parasites of pinnipeds (Mammalia: Carnivora) in Japan: checklist and bibliography. Bull Natl Res Inst Far Seas Fish 36:27-32

Ólafsdóttir D, Hauksson E (1998) Anisakid nematodes in the common seal (Phoca vitulina) in Icelandic waters. Sarsia 83:309-316

Osborn (1896) Insects affecting domestic animals. Bull Dep Agric Entomol Ser 2 5:188

Otto GF, Jackson RF (1969) Pathology of heartworm disease. J Am Vet Med Assoc 154(4):382

Pennington NE, Phelps CA (1969) Canine filariasis on Okinawa, Ryukyu Islands. J Med Ent 6(1):59-67

Perry ML (1967) A new species of Dipetalonema from the California seal lion and a report of $\mathrm{mf}$ from a Steller sea lion (Nematoda: Filaioidea). J Parasitol 53(5):469-472
Perry ML, Forrester DJ (1971) Dipetalonema odendhali (Nematoda: Filarioidea) from the northern fur seal, with description of the microfilaria. J Parasitol 57:1076-1081

Piaget E (1880) Les pédiculines. Essai monographic, Leide, p $617-660$

Popov VN (1975a) Helminth fauna of Phocidae in the Sea of Okhotsk in fall. Probl Parazitol 2:116-118

Popov VN (1975b) New data on the helminth fauna of Histriophoca fasciata Zimm. from the southern part of the Okhotsk Sea. Parazitologiya 9:31-36

Pouvreau B, Duguy R, Alzieu C, Babin P (1980) Capture d'un phoque a crete, Cytophora cristata (Erxleben, 1777), sur la cote francaise atlantique et recherches sur sa pathologie. Bull Cent Etud Rech Sci Biarritz 13(1):7-12

Raga JN (1992) Parasitismus bei den Pinnipedia. In: Niethammer J, Krapp F (eds) Handbuch der Säugetiere Europas, Band 6, Teil II: Meeressäuger (Robben). AULA-Verlag, Wiesbaden, p 41-75

Railliet MA, Henry A (1910) Sur une filaire péritonéale des porcins. Bull Soc Pathol Exot 4:386-389

Reijnders PJH, Clausen B, van Haften J, van der Kamp J (1981) Diseases and parasites in harbour seals of the Wadden Sea. Mar Mamm Wadden Sea 7:33-37

Sacks BN, Chomel BB, Kasten RW, Chang CC, Sanders RK, Leterme SD (2002) Validation for use with coyotes (Canis latrans) of a commercially available enzyme-linked immunosorbent assay for Dirofilaria immitis. Vet Parasitol 109: $45-58$

Sarich VM (1969) Pinniped phylogeny. Syst Zool 18(4): $416-422$

Sato T, Higuchi T, Shibuya H, Ohba S, Nogami S, Shirai W, Watanabe H, Honda S (2002) Lingual squamous cell carcinoma in a California sea lion (Zalophus californianus). J Zoo Wildl Med 33(4):367-370

Scherf H (1963a) Ein Beitrag zur Kenntnis zweier Pinnipedierläuse (Antarctophthirius trichechi Boheman und Echinophthirius horridus Olfers). Parasitol Res 23:16-44

Scherf H (1963b) Robbenläuse. Mikrokosmos 52(2):359-364

Schilling, Gurlt FA (1857) Verzeichnis der Thiere, auf welchen Schmarotzerinsekten leben. Arch Naturgeschichte 23:276-281

Schroeder RJ, Delli Quadri CA, McIntyre RW, Walker WA (1973) Marine mammal disease surveillance program in Los Angeles County. J Am Vet Med Assoc 163(6):580-581

Schumacher U, Horny HP, Heidemann G, Schultz W, Welsch U (1990) Histopathological findings in harbour seals (Phoca vitulina) found dead on the German North Sea coast. J Comp Pathol 102(3):299-309

Schumann W (1989) Seehunde im Wattenmeer, 2nd edn. Landbuch-Verlag, Hannover

Shults LM (1982) Helminth of the spotted seal, Phoca largha from the Bering Sea. J Wildl Dis 18(1):59-62

Shults LM, Frost KJ (1988) Helminth parasites of ribbon seals, Phoca fasciata, in the Bering Sea and their intermediate hosts. Proc Helminthol Soc Wash 55(1):68-73

Skírnisson K, Ólafsson E (1990) Parasites of seals in Icelandic waters, with special reference to the heartworm Dipetalonema spirocauda Leidy, 1858 and the sucking louse Echinophthirius horridus, Olfers, 1816. Natturufraedingurinn 60(2):93-102

Stobo WT, Fanning LP, Beck B, Fowler GM (2002) Abundance and maturity of three species of parasitic ansiakine nematodes (Pseudoterranova decipiens, Contracaecum osculatum, Anisakis simplex) occurring in Sable Island harbour seals (Phoca vitulina). Can J Zool 80:442-449

Strauss V, Claussen D, Jäger M, Ising S, Schnieder T, Stoye M (1991) The helminth fauna from the common seal (Phoca 
vitulina vitulina Linné, 1758) of the Wadden Sea in Lower Saxony. Part 1. Trematodes, cestodes, acantocephala. J Vet Med Ser B 38:641-648

Stroud RK, Dailey MD (1978) Parasites and associated pathology observed in pinnipeds stranded along the Oregon coast. J Wildl Dis 14:292-298

Sukhdeo MVK, Sukhdeo SC (2004) Trematode behaviours and the perceptual worlds of parasites. Can J Zool 82:292-315

Svobodová Z, Svobodová C, Genchi C, Forejtek P (2006) The first report of authochthonous dirofilariosis in dogs in the Czech Republic. Helminthologia 43(4):242-245

Sweeney JC (1973) Management of pinniped diseases. Am Assoc Zoo Vet An Proc 1972/73: p 141-171

Sweeney JC (1974) Common diseases of pinnipeds. J Am Vet Med Assoc 165(9):805-810

Sweeney JC (1978) Clinical consideration of parasitic diseases. In: Fowler ME, Sauders WB (eds) Zoo and wild animal medicine. WB Saunders, Philadelphia, PA, p 596-599

Taylor AER, Brown DH, Heyneman D, McIntyre RW (1961) Biology of filarioid nematode Dipetalonema spirocauda (Leidy, 1858) from the heart of captive harbour seals and sea lions, together with pathology of the hosts. J Parasitol 47:971-976

Teilmann J, Born EW, Aquarone M (1999) Behaviour of ringed seals tagged with satellite transmitters in the North Water polynia during fast ice formation. Can J Zool 77: 1934-1946

Thompson PM, Corpe HM, Reid RJ (1998) Prevalence and intensity of the ectoparasite Echinophthirius horridus on harbour seals (Phoca vitulina): effects of host age and interannual variability in host food availability. Parasitology 117:393-403

Tijskens J (1969) Le pou parasitant le phoque du lac Baikal (Echinophthirius horridus baicalensis Ass). Zoo Anvers 34: 132-134

Todd ST, Howland TP (1983) Transplacental transmission of Dirofilaria immitis microfilariae in the dog. J Parasitol 69(2):371

Treshchev VV, Yurakhno MV (1975) On the helminth fauna of Pusa hispida. Problemy Parazit 2:215-217

Turner EC (1971) Fleas and lice. In: Davis JW, Anderson RC (eds) Parasitic diseases of wild mammals. Iowa State University Press, Ames, IA, p 65-77

Editorial responsibility: Michael Moore, Woods Hole, Massachusetts, USA van den Broek E (1963) Mededelingen betreffende parasitologisch onderzoek bij de gewone zeehond, Phoca vitulina L. Lutra 5:22-30

van den Broek E, Jansen JJr (1964) Parasites of animals in the Netherlands. Suppl II. Parasites of wild mammals. Bijdr Dierkd 34:103-105

van den Broek E, Wensvoort P (1959) On parasites of seals from the Dutch coastal waters and their pathogenity. Saeugetierkd Mitt 7:58-61

van der Kamp JS (1982) Sctiebevindingen bij zeehonden, gestorven in de creche te Pieterburen. Tijdschr Diergeneesk 107:375-378

van der Kamp JS (1987) Pulmonary diseases in seals - a histopathological review. Aquat Mamm 13(3):122-124

van Haaften JL (1982) Sectiebevindingen bij in de natuur gestorven zeehonden. Tijdschr Diergeneesk 107:379-383

Vauk G (1973) Beobachtungen am Seehund (Phoca vitulina L) auf Helgoland. Z Jagdwiss 19:117-121

Vercruysse J, Salomez A, Ulloa A, Alvinerie M, Osterhaus A, Kuiken T (2003) Efficacy of ivermectin and moxidection against Otostrongylus circumlitus and Parafilaroides gymnurus in harbour seals (Phoca vitulina). Vet Rec 152: 130-134

von Dalla-Torre K (1809) Anoplura. In: Wytsman P (ed) Genera Insectorum. Verteneuil \& Desmet, Bruxelles

von Olfers IFRM (1816) De vegetativis et animatis corporibus in corporibus animatis reperiundis commentarius. Maurer, Berlin, 1:80-84

von Sprehn C (1966) Helminthen der Robben (Pinnipedia) des nördlichen Atlantik, des europäischen Nordmeeres und des nördlichen Eismeeres. Angew Parasitol 7:172-179

Wallach JD (1972) The management and medical care of pinnipeds. J Zoo Anim Med 3:45-72

Wang LC (1998) Evaluation of quantitative buffy coat analysis in the detection of canine Dirofilaria immitis infection: a model to determine its effectiveness in the diagnosis of human filariasis. Parasitol Res 84:246-248

Wipper E (1974) Die ökologischen und pathologischen Probleme beim europäischen Seehund (Phoca vitulina Linnè, 1758) an der niedersächsischen Nordseeküste. $\mathrm{PhD}$ dissertation, Tierärztliche Fakultät der Universität München

Wülker G (1930) Über Nematoden aus Nordseetieren. I. Zool Anz 87/88:293-302

Submitted: February 22, 2007; Accepted: May 19, 2007

Proofs received from author(s): October 2, 2007 